Technology Adoption, Vertical Coordination in Value Chains, and FDI in Developing Countries: Panel Evidence from the Dairy Sector in India (Punjab)

Saule Burkitbayeva, Emma Janssen and Johan Swinnen

\author{
Forthcoming in Review of Industrial Organization
}

\begin{abstract}
(Global) value chains have contributed to agricultural technology adoption in transition countries and food export commodities in developing countries through various forms of vertical coordination, often associated with FDI. Adoption of modern technologies in agriculture is crucial for improving the productivity and welfare of poor farmers. Much less is known about how (global) value chains do (not) affect technology transfer and/or adoption in staple food chains in developing countries, and the role that FDI plays. Our paper analyses the role of value chains and FDI in farm-level technology adoption with the use of panel data from representative farm surveys in 2008 and 2015 (a period of rapid growth) in the dairy sector in India (Punjab). We find important increases in the adoption of some technologies among traditional and poor dairy farms. However, the role of vertical coordination in value chains in stimulating technology adoption among these traditional dairy farmers seems to be minor, both for domestic and for FDI companies. At the same time a sub-sector of dynamic modern dairy farms has emerged. These farms are much larger, use only modern technology, and are fully integrated in vertically coordinated value chains that support these modern farms' management and investments.
\end{abstract}

Key words: value chains, technology adoption, FDI, agriculture, developing countries, India 


\section{Technology Adoption, Vertical Coordination in Value Chains, and FDI in Developing \\ Countries: Panel Evidence from the Dairy Sector in India (Punjab)}

\section{Introduction}

The adoption of modern technologies is essential for improving agricultural productivity and is a key ingredient for achieving poverty reduction and rural development around the world. However, the adoption of modern technology has been disappointing-particularly in the poorest agricultural regions (Evenson and Gollin, 2003; Sheahan and Barrett, 2014). ${ }^{1}$

The role of value chains only recently begun to receive attention as an important source of technology transfer and adoption for small farmers (Kuijpers and Swinnen, 2016; Maertens and Vande Velde, 2017; Zilberman et al., 2019). Studies show that value chains can play a very important role in technology adoption, not just by processing companies, but also by farmers through vertical coordination and spillover effects.

With imperfect (or non-existing) technology markets, various forms of institutional innovations in value chains (such as vertically coordinated supply systems and interlinked contracting $^{2}$ ) have been introduced by up- and down-stream companies to overcome constraints and enhance farms' access to and adoption of new technologies. This process of quality and technology upgrading has been documented and analyzed in transition countries and in highvalue — often export—supply chains in developing countries (e.g., Bellemare, 2012; Bolwig et al., 2009; Dries et al., 2009; Jones and Gibbon, 2011; Kumar et al., 2016; Minten et al., 2009; Van Herck et al., 2012).

\footnotetext{
${ }^{1}$ Explanations in the literature for the failure of technology adoption include imperfections in credit, information, and labor markets: access to credit and information (Banerjee and Duflo, 2014; Bardhan and Udry, 1999; Feder et al., 1985; Feder and Umali, 1993); the importance of learning through social interactions or extension services (Cameron, 1999; Munshi, 2004; Bandiera and Rasul, 2006; Conley and Udry, 2010; Genius et al., 2013); and labor constraints (Moser and Barrett, 2006). Another reason for the farmer to not adopt the technology is when there is uncertainty about whether this investment will be rewarded. One possibility is buyer holdup at the time of delivery (Klein et al., 1978). Examples are late payments, renegotiation of prices at product delivery, and the absence of transparent and reliable quality evaluation procedures (which could lead to inappropriately rejecting produce) (Barrett et al., 2012; Cungu et al., 2008; Saenger et al., 2014).

${ }^{2}$ Such interlinked contracts are well known in the traditional development literature for basic input provisions (Bardhan, 1989; Bell and Srinivasan, 1989).
} 
However, much less is known about how value chains do (not) affect technology transfer and/or adoption in staple food chains in developing countries. This is an important gap in our understanding since most of the poor are involved in staples production rather than highvalue exports. Some recent studies have found that this process of vertical coordination and technology transfer seems to have not (yet) emerged in staple foods in developing countries (e.g., Minten et al., 2016; Rearden et al., 2009).

In this paper we contribute to our understanding of this by analyzing farm-level technology adoption and its relationship to value chains and their vertical coordination during a period of rapid demand growth in India. The analysis focuses on the dairy sector-an important sector for the poor - and uses unique panel data from company and farm-level surveys in Punjab, India, in 2008 and 2015.

The analysis builds on an earlier study using data from a single survey (in 2008) from Punjab and Andhra Pradesh (Janssen and Swinnen, 2019), which found that very little transfer of technology occurred through value chains. The same farms and companies were surveyed and interviewed again seven years later (in 2015) to analyze whether continued growth in the Indian dairy markets has resulted in more technology transfer through value chains. In addition, information was collected from a new group of modern dairy farms that had emerged during this period.

Previous empirical studies on value chains and farmers mostly rely on cross-section data, which makes it challenging to identify causal relationships between technology adoption and value chains. Our panel data allows to overcome some of the endogeneity and self-selection problems.

The dairy chain in India is a highly relevant case for several reasons: First, the Indian dairy sector is arguably the world's largest agri-food sector: It employs more than 70 million households. Second, dairy production contributes to inclusive growth, especially in India where there is a high dependency of the poor on agricultural employment. Activities such 
as dairy—which are labor-intensive but do not overly rely on access to land or economies of scale - are generally expected to offer better prospects for income growth to the poorest rural households, who are often characterized by limited access to land but easy access to cheap family labor. The Indian government has massively promoted development in the dairy sector due to its potential for 'pro-poor' growth, for example, through its "Operation Flood" program to increase small farmers' income. It was launched in 1970 and soon became one of the world's largest rural development programs. ${ }^{3}$

Third, value chains induced technology adoption by (large and small) dairy farmers have been documented in other emerging and developing economies: e.g., in numerous Eastern European countries during transition (Dries et al., 2009) and, more recently, in East African dairy export chains (e.g., Van Campenhout et al., 2019). Although different in some aspects, these regions shared key characteristics with India in the past 15 years: in particular, a combination of growth in the demand for (better quality) milk products and imperfect (or missing) credit and technology markets.

Incomes have been increasing rapidly in India over the past 25 years, which has created a strong growth in demand for milk products (see Section 2). In addition, rapid urbanization and the spread of modern retail in India have contributed to a demand for high-quality products and safety standards (Minten and Reardon, 2008; Reardon and Timmer, 2014). While demand growth over the past 25 years was initially mostly driving the need for higher quantities of milk supplies, more recently there has been increasing demand for better quality and safety of milk products (Squicciarini and Vandeplas, 2013).

Fourth, technology transfer through vertical coordination has been observed in "global" food value chains: either through trade, where value chains link "rich consumers" with "poor

\footnotetext{
${ }^{3}$ India has also used these arguments in trade negotiations - both within the World Trade Organization (Jha, 2003) and in bilateral negotiations (Mondal et al., 2012) — to keep the dairy sector largely off the negotiation table (Goswami, 2007).
} 
producers" through high-value food exports (e.g., Maertens and Swinnen, 2009; Minten et al., 2009), or through foreign direct investment (FDI), where multinational food and retail companies have triggered important value chain changes in transition and emerging countries, sometimes with spillover effects on local companies (Dries and Swinnen, 2004; Gow and Swinnen, 2001; Gow et al., 2000). The dairy value chains in our study are entirely domestic, but there has been important investment from a foreign dairy multinational (Nestlé), which is sourcing from a sizeable group of farms in our survey. This thus allows us to compare differences in value-chain structures and relationships with farmers between domestic and foreign companies.

The paper is organized as follows: Section 2 presents a conceptual framework for how institutional innovations in value chains can help technology adoption by farmers. Section 3 provides information on the dairy sector and value chains in India and Punjab. Section 4 presents the data. Sections 5 and 6 present descriptive and econometric results. Section 7 presents additional findings on a new emerging modern dairy industry, and Section 8 concludes.

\section{Technology Adoption and Value Chains in Developing Countries: A Conceptual}

\section{Framework $^{4}$}

Consider a farmer with a fixed allocation of labor and land who uses "basic technology" to produce a quantity $q_{0}$ of a low-quality product that can be sold in the local market for a price $p_{0}$. The farmer's alternatives are to sell to a trader, a processor, or a retailer (who we refer to collectively as "the buyer"). The buyer processes and sells the product to urban consumers. To keep the model simple, we assume that processing and marketing costs are zero.

The buyer requires specific standards or minimum amounts of supply from the farm. A more advanced technology ${ }^{5}$ allows the farmer to comply with the buyer's private standard

\footnotetext{
${ }^{4}$ This conceptual framework draws on the models developed in Vandemoortele et al. (2012), Swinnen et al. (2015) and Swinnen and Kuijpers (2019).

${ }^{5}$ Here, we keep the definition of "technology" general. Later we consider different types of technology.
} 
and/or increases the farmer's productivity, which is reflected in a higher quantity produced $q_{H}$ (with $q_{\tau} \geq q_{0}$ ) that is sold at a price. ${ }^{6}$ The total value that is generated by applying the advanced technology is $V_{\tau}=p_{\tau} q_{\tau}$. The farmer can buy the technology from a company at an opportunity cost of $\tau^{f}$ that is reflected in a higher price $\left(p_{\tau} \geq p_{0}\right)$. With $V_{0}=p_{0} q_{0}$ as the farmer's opportunity cost, the net surplus that is created by adopting the technology is $S=V_{\tau}-V_{0}-\tau^{f}$. This is the total surplus in the value chain from technology adoption. The farmer's net surplus is $S^{f}=V_{\tau}^{f}-V_{0}-\tau^{f}$ with $V_{\tau}^{f}=\theta p_{\tau} q_{\tau}=\theta V$ and $\theta$ representing the farmer's share of the consumer price for the high-value product. The farmer will decide to adopt the technology if his net surplus $S^{f}$ is positive: if

(1) $\quad V_{\tau} \geq \frac{\left(\tau^{f}+V_{0}\right)}{\theta}$

This condition holds in domain D in Figure 1.

This general condition captures both the quantity and quality effects of technology adoption. All else equal, technology adoption is more likely if: its quantity effect on productivity $\left(q_{\tau}-q_{0}\right)$ is larger; if the quality effect $\left(p_{\tau}-p_{0}\right)$ is stronger; if the farmer's share of the consumer price $\theta$ is larger; if the price of technology $\tau^{f}$ is lower, and if the opportunity costs of the farmer $V_{0}$ are lower.

\subsection{Vertical Coordination in Value Chains}

Many farmers in countries such as India face technology and credit market imperfections, which makes buying the technology difficult and expensive. The buyer may have better access to the modern technology than does the farmer when the buyer has: less-stringent credit and liquidity constraints; or lower transaction costs due to economies of scale; or lower information asymmetries if the buyer has better knowledge of consumer preferences. The buyer can then

\footnotetext{
${ }^{6} \mathrm{We}$ ignore the possibility that there is a trade-off between quantity and quality. Such trade off may well exist for given technologies and for some technological innovations. However, many of the technologies that are relevant in our analysis increase both quantity and quality, or at least increase one without reducing the other.
} 
offer the farmer a contract that includes the transfer of technology and conditions for purchasing the product (time, amount and price). We refer to the buyer's opportunity cost of the technology transfer as $\tau<\tau^{f}$. This opportunity cost will depend on the cost of transfer, as well as on the buyer's potential return to alternative investments (including alternative sourcing contracts). This means that — in the absence of a contract — the buyer's "disagreement payoff" is equal to $\tau$.

For simplicity, we assume that the farmer's "disagreement payoff" is equal to $V_{0}=$ $p_{0} q_{0}$. The buyer's and farmer's participation constraints are then defined as $\Pi^{B} \geq \tau$ and $\Pi^{f} \geq$ $V_{0}$, with $\Pi^{B}$ and $\Pi^{f}$ denoting the buyer's and farmer's contract payoff, respectively. The total (net) surplus that is created by the technology transfer and the contract is $S=V_{\tau}-V_{0}-\tau$.

The division of the contract surplus can be modeled as a Nash bargaining problem, where each party receives his or her disagreement payoff and a share of the contract surplus. ${ }^{7}$ We denote the share that accrues to the farmer as $\beta$, with $0 \leq \beta \leq 1 .^{8}$

Consider first, as a benchmark, the case that contracts are always perfectly enforced. In this case, given the disagreement payoffs of both parties, the contract payoffs are

$$
\begin{aligned}
& \Pi^{f^{*}}=V_{0}+\beta S=V_{0}+\beta\left(V_{\tau}-V_{0}-\tau\right) \\
& \Pi^{B^{*}}=\tau+(1-\beta) S=\tau+(1-\beta)\left(V_{\tau}-V_{0}-\tau\right)
\end{aligned}
$$

where superscript ${ }^{*}$ denotes the payoffs with perfect enforcement. Under these assumptions, the technology transfer will take place if the net surplus is positive, i.e. if

$$
V_{\tau} \geq \tau+V_{0}
$$

The value created $\left(V_{\tau}\right)$ should be larger than the opportunity costs of labor $\left(V_{0}\right)$ and of transferring the technology $(\tau)$. This condition holds for domains $\mathrm{B}+\mathrm{C}+\mathrm{D}$ in Figure 1 . Technology transfer is more likely if the effect on the value of the farmer's product $\left(p_{\tau}-p_{0}\right)$

\footnotetext{
${ }^{7}$ See Swinnen and Vandeplas (2010) for more details.

${ }^{8}$ Here, we assume that this sharing rule $\beta$ is determined through ex-ante bargaining. Swinnen and Kuijpers (2019) show how the ex post division of surplus depends on contract enforcement and holdup opportunities.
} 
or on the production efficiency $\left(q_{\tau}-q_{0}\right)$ is higher; if the buyer's opportunity cost of transferring the technology $\tau$ is lower; and if the opportunity costs of labor $V_{0}$ are lower.

Contracts such as the one described here may be formal or informal. In either case, contract enforcement is nontrivial. With imperfect contract enforcement, contracting and technology transfer might not occur. Contract breach can take many forms in countries such as India. For example, the farmer could decide to divert the technology provided by the buyer by selling it or using it for different purposes. Another example is that the farmer defaults on the contract by selling the product to an alternative buyer-after applying the transferred technology. Such "side-selling" can be profitable as the alternative buyer does not have to account for the cost of the provided technology.

Consider the case of farmer hold-up through technology diversion. ${ }^{9}$ If the farmer diverts the technology, we assume that the benefit equals the cost of the technology for the buyer $\tau .^{10}$ In addition, the farmer can still realize his opportunity cost of labor $V_{0}$. By violating his contract, the farmer suffers a reputation $\operatorname{cost} \phi \geq 0$. Hence, with technology diversion, the farmer's payoff is $\Pi_{d}^{f}=V_{0}+\tau-\phi$, and the buyer's payoff is $\Pi_{d}^{B}=0 .{ }^{11}$

In the event that there is no external contract enforcement (beyond what is captured in the reputation costs) the partners can try to design the contract to be "self-enforcing" to avoid holdups and make the technology transfer work. For the contract to be self-enforcing, the farmer's contract payoff must at least equal his holdup payoff $\Pi_{d}^{f}$, while the buyer's payoff must at least equal his disagreement payoff $\tau$. In other words, the technology transfer contract should satisfy the farmer's incentive compatibility constraint $\left(\Pi^{f} \geq \Pi_{d}^{f}=V_{0}+\tau-\phi\right)$ and the

\footnotetext{
${ }^{9}$ Although side-selling by farmers potentially affects the occurrence of technology transfer in a slightly different way than technology diversion, it is conceptually similar (see Swinnen et al. (2015)). We have not included this to reduce the complexity of the analysis. The extended analysis for side-selling can be obtained from the authors.

${ }^{10}$ We relax this assumption in the section where we look at different types of technologies.

${ }^{11}$ Note that in this model $\tau$ and $V_{0}$ are "sunk" costs, which is why they do not directly show up in the buyer and farmer's payoffs. These costs will be reflected in the buyer and farmer's participation constraints.
} 
buyer's participation constraint $\left(\Pi^{B} \geq \tau\right)$. Combining these, the value that is generated by the transfer should satisfy the following condition for the contract to be feasible:

$$
V_{\tau} \geq V_{0}+2 \tau-\phi
$$

in addition to the condition $V_{\tau} \geq V_{0}+\tau$, which was determined earlier (equation 4). This implies that technology transfer in value chains is possible when

$$
V_{\tau} \geq V_{\tau}^{\min }=\max \left\{V_{0}+\tau ; V_{0}+2 \tau-\phi\right\}
$$

If $V_{\tau}$ is sufficiently high, it is possible to adjust the contract terms to satisfy the farmer's incentive compatibility constraint without violating the buyer's participation constraint, which makes the contract, in principle, feasible. A low $V_{\tau}$, however, might be insufficient to pay the farmer at least his holdup payoff and prevent contract breach. In this case, a self-enforcing contract will not be possible. It is clear that holdup is only profitable for the farmer if the benefit of diverting the technology is greater than his reputation cost: if $\tau>\phi$. If $\tau \leq \phi$, the farmer has no incentive to hold up the buyer, and the "efficiency" condition (equation 4) remains binding. These conditions hold in domains $\mathrm{C}+\mathrm{D}$ in Figure $1 .{ }^{12}$

In summary, technology transfer through value chain contracting is more likely when the value that is generated by the technology, the farmer's reputation costs are higher, and when the farmer's best alternative to the buyer's offer, and farmer's and buyer's opportunity costs are lower.

\section{$2.2 F D I$}

Empirically, studies have highlighted the important role of FDI in stimulating these value-chain innovations. ${ }^{13}$ There are several reasons why FDI can play a role: One is that multinational companies often have access to cheaper capital and technology, making it easier

\footnotetext{
${ }^{12}$ Note that there may also be buyer hold-up of the contract. For example, the buyer may want to renegotiate the contract and refuse to pay the farmer the agreed share of the value at product delivery. Instead, he may offer to pay only as much as the farmer's best alternative at that moment (e.g. the value of the produce when sold on the local market). We do not model this here and refer to Swinnen and Kuijpers (2019) for a formal analysis.

${ }^{13}$ See, e.g., World Bank (2005) in transition countries and Maertens et al. (2011) in developing countries.
} 
to finance the technology transfer (thus a lower buyer opportunity cost of transferring $\tau$ ). Another is that multinational companies often target higher-income groups as consumers and sell higher-value products (thus a higher $V_{\tau}$ ). Foreign companies typically also have more expertise and knowledge as to how value-chain structures and vertical coordination programs have worked (or not) in other countries.

\subsection{Consumer income growth and heterogeneous farms}

So far we have modeled the supply side as a representative farmer. In reality, farmers are heterogeneous. To allow for this, consider, as in Vandemoortele et al. (2012), that farmers differ in their opportunity cost of capital, with $\tau_{i}^{f}$ the opportunity cost of capital of farmer $i$. This implies that total technology adoption among farmers will be positively correlated with value. With a uniform distribution of capital costs, this relationship will be linear - as is illustrated by the technology adoption function $T(V)$ in the upper-right panel (b) of Figure 2. $\mathrm{T}(\mathrm{V})$ represents aggregate technology adoption without vertical coordination. With vertical coordination, technology adoption as a function of value is represented by function $\mathrm{T}^{\mathrm{VC}}(\mathrm{V})$, which lies to the right of the $\mathrm{T}(\mathrm{V})$ function with technology adoption higher with vertical coordination for specific values. If we assume that growth in consumer income translates into growing demand, and thus gross value, as represented by function V(I) in in the upper-left panel of Figure 2, it is now possible to derive how technology adoption changes with income growth, as is illustrated in the lower left panel (d) of Figure 2. As income increases from $I_{1}$ to $\mathrm{I}_{2}$, technology adoption increases from $\mathrm{T}_{1}$ to $\mathrm{T}_{2}$ without and from $\mathrm{T}_{1}{ }^{\mathrm{VC}}$ to $\mathrm{T}_{2}{ }^{\mathrm{VC}}$ with vertical coordination.

\subsection{Types of Technology}

"Technology" can capture a variety of factors that affect quality or productivity, including (improved) feed; animals; knowledge; or specific investments, such as cooling 
equipment in dairy. While all of these technologies have some common features, which allows them to be modeled as we did above, they also differ in important aspects:

One aspect is the time dimension of the technology transfer. Some technologies need to be provided every production period: e.g., such as animal feed. Other technologies affect the production process beyond the current period: e.g., such as knowledge or training; equipment; or investments in traceability systems. These technologies provide long-term effects, beyond what is realized in one production cycle. It is likely that the transfer of technologies with shortterm value effects is easier than that of technologies that have longer-term benefits, because the benefits are more likely to be captured in the contract period. ${ }^{14}$

Another important aspect relates to how specific the technology is for the transaction between buyer and farmer. ${ }^{15}$ This will affect the value of the technology when the farmer diverts the technology (we assumed this value is $\tau$ ). This value will depend on the specificity of the technology. The alternative value of the product after production with the technology has taken place also matters. The transferred technology is fully specific to the transaction if it has no value to others. The specificity of the technology affects the holdup opportunities of both the farmer and the buyer, and therefore the feasibility of contracting with technology transfer.

Some technologies - e.g., longer-term investments; low ex-ante specificity; high expost specificity - are more difficult to transfer through value chains. Therefore, empirical studies do show that this is still possible with specific value-chain governance such as triangular structures that involve processing companies (buyers), financial institutions, technology providers, etc. (see e.g., Dries et al. (2009) for cooling equipment in dairy in transition countries). Including other companies that also benefit from the technology transfer in the

\footnotetext{
${ }^{14}$ More formally, using parameter $\sigma$ to represent the share of the gross surplus that is obtained in the contract period, the net surplus of technology adoption is $S=\sigma\left(V_{\tau}-V_{0}\right)-\tau+\frac{\mu(1-\sigma)}{1+\delta}\left(V_{\tau}-V_{0}\right)$ : where $\mu$ represents the probability that the remaining gross surplus from the technology transfer is realized in the future (with $0 \leq \mu \leq$ 1 ); and $\delta$ represents the discount rate. It follows that the surplus requires a larger value to be positive and grows slower with increasing value.

${ }^{15}$ Our concept of "technology specificity" is obviously related to "asset specificity" in the transaction cost literature (e.g., Williamson, 1985).
} 
contract spreads the risk and costs of contract breach and enhances the enforcement capacity through lower information asymmetries and higher reputation costs (Swinnen and Kuijpers, 2019).

\subsection{Hypotheses}

This model yields some important hypotheses for technology adoption in Indian dairy: A first hypothesis is that technology adoption will emerge when the demand for milk increases with income growth. A second hypothesis is that value chains can play an important role in facilitating technology adoption by farmers through vertical coordination that is initiated by dairy processing companies. Because of important credit and technology market imperfections in rural areas, these buyers may assist farms in accessing technologies through contracting and farm support programs. These contracts may be formal or informal, but are more likely to be initiated by buyers that are less capital-constrained themselves, such as larger and modern dairy processors. The contract can be short run (e.g., for animal feed) or longer run (e.g., for investments in animals or cooling equipment). A third hypothesis is that buyers are more likely to first focus on providing information and farm-level inspections (e.g., to improve hygienic practices), and later on the provision of credit or direct technology as part of contracting (e.g., better breeds and/or better feed).

In the rest of this paper, we analyze whether these hypotheses are supported by evidence from poor farmers in rural areas in India during a period of rapid income growth.

\section{Dairy and Technology in India and Punjab}

\subsection{Dairy production and consumption}

India is the largest milk-producing country in the world. Dairy is a traditional activity in many regions of India. In 2017, 75 million dairy producers in India produced more than 176 million tons of milk (FAO 2010; NDDB 2020). The value of the milk that was produced in India was \$43 billion USD, which made it India’s largest agricultural commodity by value (FAOSTAT, 
2019). Figure 3 illustrates the impressive growth of Indian dairy production. Strong income growth led to more demand for milk and milk products. Per capita milk consumption has been growing steadily over the last four decades and will continue to do so, especially in urban areas (Kumar et al., 2014). The demand for processed and packaged milk products is increasing, especially among urban populations.

Punjab, one of the leading states in terms of agricultural and dairy development states in India, produced 11.8 million tons of milk in 2017. As Figure 3 illustrates, milk production in Punjab has been growing at an average of $2.4 \%$ per year since 2000 . Punjab also has the highest per capita milk consumption in the country: equal to 1032 grams/capita/day, which is more than twice the national average of 337 grams/capita/day (NDDB, 2020). This is due to several reasons: (1) favorable agro-climatic conditions for fodder availability, (2) well-developed transport infrastructure that supports dairy commercialization; (3) comparatively higher standards of living which drives the demand for milk; and (4) extensive government support of the dairy sector (Chand, 1999; Staal et al., 2008). Punjab, which is characterized by the presence of both formal and informal value chains as well as a strong private sector (including FDI), therefore serves as an interesting location to study the effects of modern supply chains on technology adoption.

\subsection{Milk quality}

Demand growth for food products may provide incentives for adulteration. For example, excessive demand growth contributed to milk adulteration and major food safety problems (the “milk scandal") in China in the late 2000s (Mo et al., 2012). A series of food scandals ${ }^{16}$ in India in the early 2000 s increased national awareness of safety concerns in the production, processing, and marketing of food (Squicciarini and Vandeplas, 2010). This caused debates on

\footnotetext{
${ }^{16}$ It was revealed that bottled water, milk and soft drinks contained dramatically high pesticide residue levels (Umali-Deininger and Sur, 2007).
} 
the need to introduce safety and quality standards for milk, which led to the introduction of the Food Safety and Standards Act (FSSA) in 2006. ${ }^{17}$ The Food Safety and Standards Authority of India (FSSAI) was established in 2011 to oversee the implementation of this Act. However, a recent audit of the FSSA showed that the policy has been implemented poorly (CAG, 2017). Anticipation of proper implementation of the legislation - in conjunction with increasing pressure from consumers - may spur the emergence of private food standards in the Indian dairy industry.

Squicciarini and Vandeplas (2010) report that Indian dairy processors decided to pursue different levels of Hazard Analysis and Critical Control Points (HACCP) and International Organization for Standardization (ISO) certification as a 'competitive' strategy, in an attempt to convince consumers that their milk is of high quality. However, it is unclear how far these changes have spread along the value chain and to what extent these efforts have affected the farm-level activities.

\subsection{Value Chain Structure}

Figure 4 illustrates the structure of the dairy supply chains in Punjab. There are several possible outlets for the milk produced by the dairy farms.

Small dairy farms use part of their produced milk for home consumption and sell the rest informally: either directly to neighbors or friends, or to informal milk traders (dudhiyas). These dudhiyas pick up the milk from the small farmer's doorstep and directly market it to other households within the (neighboring) village(s).

\footnotetext{
${ }^{17}$ In 2006, Indian policy makers, pressured by civil society protests, drafted the Food Safety and Standards Act (FSSA). The Act determines which actor in the supply chain bears responsibility when food safety regulations are not complied with (Article 27 of FSSA 2006). For milk traders this implies that they are liable for any adulterants (e.g., water, oil, skimmed milk powder, soda) that is added to the milk, even if the responsibility for adulteration lies with their suppliers - unless they can specifically identify the culprit (Squicciarini and Vandeplas, 2013). These regulations extend to informal traders including street hawkers and itinerant vendors. Opponents of the Act claim that poor street vendors will be unable to comply with the food standards that have been imposed. Despite the existence of the FSSA, a wide number of procedures, guidelines and mechanisms are yet to be framed by the Food Safety and Standards Authority of India (FSSAI).
} 
Traditionally, the main formal processing was in cooperative dairies (Cunningham, 2010). In Punjab, the cooperative sector is mainly represented by the Punjab State Cooperative Milk Producers Federation Ltd., also known as Milkfed, or Verka-its brand name. Cooperatives procure milk from small dairy farms through village level collection centers.

Since 1991, when de-licensing of dairy companies was introduced, private dairy companies have been allowed. In Punjab, private dairy companies procure milk from small dairy farms either through private milk buyers or milk collection centers. An important private dairy company in the region is Nestlé: a well-known multinational dairy company.

Finally, it also common for larger commercial dairy farmers to supply milk directly to processing plants (cooperatives, Nestlé or domestic private companies) and their milk is collected on the farm by the dairy companies.

\subsection{Technology adoption in dairy production}

Increased demand and changes in consumer preferences that have accompanied higher incomes could give the dairy sector incentives and means to invest in new technologies. Demand-driven institutional innovations - in particular, vertical coordination-have contributed to farm assistance programs led by dairy processors to help farms invest in new technologies and improve milk quality and safety in other countries (see, e.g., Dries et al., 2009). In the Indian dairy context, improvements in technology and production practices relates to several elements (Janssen and Swinnen, 2019):

First, milk quality can be enhanced by improving basic hygienic and food safety practices. Hygienic practices — which include washing hands, utensils, and the udder and teats of dairy animals (DA) before, during, and after the milking process — are crucial to ensuring high quality milk (Kumar et al., 2011). Moreover, given India's climatic conditions, timely cooling, storage and preservation practices are crucial to guarantee safe milk. 
Second, an important area for increasing productivity is improving the quality of animal feed. Feed scarcity and limited affordability was found to be a major constraint to higher milk yields (Nagrale et al., 2015; Birthal and Jha, 2005). Beside dry and green fodder, a balanced diet for better productivity should include concentrated feed to ensure the intake of sufficient protein, energy, minerals, and vitamins. The nutrients should also be administered in amounts that match the physiological needs of the DA, which vary with status (pregnant, in milk, dry) and type (FAO, 2012).

Third, another important technology to increase yields are cross-bred cows. Crossbreeding is widely implemented as a means of genetic and, essentially, productivity improvement. ${ }^{18}$ In India, cross-bred cows are a result of inseminating local (desi) cows with foreign (exotic) breeds such as Holstein-Friesian (H.F.) and Jersey. The cross-bred cows, with proper feeding, are significantly more productive in terms of milk yield than are their indigenous (desi) counterparts.

\section{Data}

Our analysis relies on a unique two round survey of small dairy farms in rural Punjab. The baseline was collected in the summer of 2008, and the follow-up round occurred seven years later in 2015 during the same period. This analysis is complemented with information from a series of interviews in 2015 with a group of modern dairy farms that started after 2008.

During the first round, Punjab was divided into five regions (see Figure 5). Districts were selected at random from each of the five regions with the probability of selection proportional to district's population share within that region. ${ }^{19}$ All villages within the selected

\footnotetext{
${ }^{18}$ Cross-breeding practices in India date back to mid 19th century (Sinha, 1951). Cross-breeding on a large scale, however, began only in 1963 with the introduction of the Intensive Cattle Development Project (ICDP) as part of the Special Development programme during the Third Five-Year Plan period (Rao et al., 1995). Since then, the share of cross-bred cows in cattle milk production has been increasing steadily and reached 53\% in 2011 (Kumar et al., 2013).

${ }^{19}$ The north-west (Amritsar and Gurdaspur), the north-east (Hoshiarpur, Jalandhar, Kapurthala and Nawanshahar), the south-west (Bathinda, Faridkot, Ferozepur, Moga and Muktsar), the south-east (Mansa, Patiala, and Sangrur), and the central region (Fatehgarh Sahib, Ludhiana, and Ropar) (see Figure 5).
} 
districts were stratified according to various marketing channels. To also measure the effect of FDI (the presence of the foreign processor, Nestlé), we selected at random 15: 'Nestlé villages'; 15 'cooperative villages'; five villages where both companies were expected to operate; and 15 villages without Nestlé or cooperatives, spread over the five selected districts. Finally, we selected six villages from Amritsar, six in Hoshiarpur, 14 in Ludhiana, 18 in Ferozepur, and six in Mansa. Using a prior village census, 20 small dairy farms from each village were stratified and chosen at random.

During the second round in 2015 , the goal was to resurvey all the small dairy farms from the original sample to generate evidence on the dynamics of participation in different marketing channels. In each round, the same questionnaire was used to collect information on small dairy farms' socio-economic characteristics, and particularly on their dairy production practices and use of inputs and output markets. We were not able to locate 130 small dairy farms, which is a $13 \%$ attrition rate. Ultimately, we have a balanced panel of 1750 observations across two rounds, with 633 farmers who had DA in both rounds.

\section{Descriptive Evidence}

\section{1 (Changes in) the dairy value chain structure}

Table 1 documents the importance of the various channels and how their importance has changed between 2008 and $2015 .^{20}$ The data reveal some important changes, and several of these changes are counterintuitive given the significant growth in dairy production and consumption.

In $2008,25.5 \%$ of the dairy farmers did not sell any milk, and this share increased to $29.1 \%$ in 2015 . The share of farms that sold informally increased greatly: from $13.6 \%$ in 2008 (of which $2.3 \%$ directly to other households and $11.3 \%$ to informal milk traders) to $25.7 \%$ in

\footnotetext{
${ }^{20}$ Table 2 includes all dairy farmers in the sample. Table $1 \mathrm{~A}$ in the appendix shows the same table including only those dairy farms that had DA in both 2008 and 2015.
} 
2015 (of which $10.2 \%$ to other households and $15.5 \%$ to informal milk traders). In contrast, the share of dairy farmers that sold to formal dairy channels declined from $61.0 \%$ to $45.5 \%$. These changes are somewhat surprising since one would have expected growth in dairy markets to be associated with a growing share of formal sales.

The share of all formal channels declined. The share of farms selling milk to cooperatives declined from $22.1 \%$ in 2008 to $18.5 \%$ in 2015 . The most important cooperative (Verka) stopped buying milk in four of our sample villages, where $41.2 \%$ of the dairy farms that were selling milk in 2008 were supplying to Verka. At the same time, Verka started procuring in five new villages but only managed to capture $28.6 \%$ of the sample dairy farms that sold milk in these villages. Furthermore, in two of our sample villages, there was a remarkable decline in dairy farms that sold to Verka: from $83.3 \%$ in 2008 to $10.5 \%$ in 2015 (average for the two villages). No specific reasons for this were cited in the survey. At the same time, Mother Dairy, another cooperative, entered three of our sample villages and sourced from $23.7 \%$ of the dairy farms that sold milk.

The decline in sales was even sharper in the private sector, and especially for Nestlé. The share of dairy farms that sold to private dairy companies fell from $38.9 \%$ in 2008 to $26.9 \%$ in 2015 . The share that sold to private domestic dairies declined from $14.2 \%$ to $12.6 \%$. The decline was especially large for dairy farms that sold to Nestlé: from $24.7 \%$ in 2008 to $14.4 \%$ in 2015. The significant decline in dairy farms that sold to Nestlé can be partly explained by a restructuring of their sourcing across villages and by reputational problems. Nestlé ceased procurement activities in five of our sample villages, where, on average, $67 \%$ of the dairy farms that were selling milk sold to Nestlé. The company opened new collection centers in only two of our sample villages, where, on average, $58 \%$ of the dairy farms that sold milk now sell to Nestlé. Furthermore, in one village, $50 \%$ of the dairy farms that used to sell to Nestlé in 2008 indicated that they stopped selling to the company because they suspected the manager of Nestlé's collection center of cheating them on fat measurements. 


\subsection{Farm characteristics and value chain choices}

Table 2 presents the distribution of dairy farms by marketing channels based on herd and land size. A first observation is that sales of milk have increased strongly in the 3-10 DA category: Their share in the "no sales" category fell from $46 \%$ to $17 \%$. In 2015 , the dairy farms that did not sell milk were almost exclusively (83\%) farms with only one or two DA. Another observation is that very small milk producers (1-2 DA) make up a larger share of the supply base for the informal sector ( $61 \%$ and $50 \%$ to households and informal traders, respectively) but also a significant share of suppliers to the formal sector (between $29 \%$ for cooperatives to $39 \%$ for Nestlé). This indicator suggests that there is no obvious "exclusion" of small dairy farmers from formal value chains - neither domestic nor FDI. All farms with 10 DA or fewer make up more than $90 \%$ of the suppliers of formal channels. These farmers also represent around $60 \%$ of the amount of milk that was supplied to formal channels.

In summary, there have been significant changes in the importance of the various channels in the value chains. There has been a significant increase in the share of medium size farms (DA between 3 and 10) that sell milk. Small farms (with one or two DA) sell mostly to informal channels, but still represent a significant share of the suppliers of the formal private and cooperative dairy companies. In section 5 we analyze how technology adoption has evolved between 2008 and 2015 and how this is related to the supply channels.

\subsection{Contracting}

As discussed earlier, contracts between buyers and suppliers are very important in technology transfer and value chain development. Interestingly, we did not find any evidence of contracts (not even oral agreements) between dairy farmers and milk buyers in Punjab for the farmers in our sample in either 2008 or 2015 . These findings seem to contrast with the findings of Birthal et al. (2017) who report that in Punjab the multinational dairies and private local firms engage 
farmers who own larger herds (25 and more) in production on the basis of a written contract and provide them with cattle feed and equipment, such as milking machines, milk coolers, and veterinary and extension services as part of the contract. Our survey, which includes eight farms that owned 25 or more DA (five farms in 2008 and three farms in 2015) did not reveal any presence of such schemes neither in written nor in informal form.

However, we did find evidence of contracting and vertical coordination with a new group of larger farms, several of whom were new and not captured by our sample. These will be discussed in section 7.

\subsection{Technology adoption 1: hygienic practices}

Table 3 summarizes hygienic practices in Punjab in both 2008 and 2015. The vast majority of the dairy farms washed their hands before milking and in between milking different animals. This decreases the likelihood of transmitting infections between DA. In 2015, 56.8\% of the dairy farms reported using soap, detergent or disinfectant for hand washing compared to only $13.5 \%$ in 2008 . In almost all cases, udder and teats were washed before milking (only with water), to remove mud, dust and dung.

In addition, more dairy farms reported drying udders and teats in 2015 (23.4\%) compared to $2008(14.2 \%)$. Washing and drying the udder and teats decreases the probability of contamination of the milk and the exposure of the udder and/or teats to infections (mastitis).

In 2015, almost all dairy farms (99.0\%) washed their utensils at least once a day, and most importantly, more dairy farms $(79.8 \%)$ used soap, detergents or disinfectant (more than just water) compared to $2008(17.4 \%)$.

The time between milking and cooling the milk to an appropriate temperature is crucial, since in this moment the microbial content of the milk grows exponentially. The methods of milk preservation before sales did not change much between 2008 and 2015, and around 60\% 
of dairy farms did not treat (cool, boil) milk before sales: The majority reported selling milk directly after milking.

The overall improvement in hygienic practices becomes even more apparent when the changes over time (with the use of an index of hygienic practices) are examined. ${ }^{21}$ Figures 6 a and $6 \mathrm{~b}$ show that the hygiene index increased on average from 0.53 in 2008 to 0.70 in 2015 , an improvement of $31 \%$. What is also interesting is that convergence seems to have taken place. Dairy farms that were in the lowest quartile in 2008 improved their hygiene score from 0.37 to 0.70 on average (Figure 6a), which is an impressive 91 percentage change from 2008 (Figure $6 b)$. Growth is much lower for the other quartiles and even negative for the fourth quartile. The improvement in hygienic practices across all dairy farms is also confirmed by the rightward shift of the distribution of the hygienic index from 2008 to 2015 (Figure 7). Moreover, the adherence to hygienic practices has leveled up across marketing channels; there is less variability in the mean hygienic index across different marketing channels (Figure 8). ${ }^{22}$

However, dairy company incentives still seemed to be limited to minimizing time between milking and cooling by investing in collection centers that are close to the farmers. The organization of the value chain in Punjab allows for close contact between milk buyers and dairy farmers, which could serve as a vehicle for information distribution at a relatively low cost. However, while the number of dairy farms that received information on clean milk production increased significantly, by 2015 , still only $2.5 \%$ received information from their milk buyer (informal or formal) (see Table 4 Panel A). At the same time, there is a remarkable increase in the number of dairy farms that indicated that they received information on clean milk production practices from other farmers and from the government (from $0.3 \%$ in 2008 to

\footnotetext{
${ }^{21}$ The index of hygienic practices is the average of the compliance levels for various sanitary practice indicators before and during milking which are demonstrated in Table 4.

${ }^{22}$ Figures 7, 8, 10, and 12 include all dairy farmers in the sample. Figures A1 - A4 in the appendix show the same graphs but include only those dairy farms that had DA in both 2008 and 2015.
} 
$15.7 \%$ in 2015). Further, in 2015 dairy farms reported fewer on-farm inspections by both milk buyers and government institutions.

In summary, from 2008 to 2015, the adherence to hygienic practices increased significantly across all dairy farms, except for the highest quartile, and convergence between different dairy farms was observed. However, for the vast majority of dairy farmers, value chain initiatives remain focused on investment in village milk collection centers but not in providing information on and incentives for the adoption of better hygienic practices, nor in organizing inspections at the farm level.

\subsection{Technology adoption 2: animal feed}

Figure 9 and Table 4 Panel B indicate that improved feeding practices ${ }^{23}$ through the use of mixed concentrated feed were more common in $2015(68.8 \%)$ than in 2008 (53.3\%). The greatest increase in the use of mixed feed is among dairy farms that did not use mixed feed at all in 2008; 67\% of them reported using mixed feed in 2015 (Figure 9). More so, Figure 10 shows that the share of dairy farms using mixed feed increased across all marketing channels from 2008 to 2015 .

Value chains could improve the accessibility of good-quality mixed feed. Most dairy companies told us during our company interviews in Punjab that they offered mixed feed to their farmers at production costs and that some provided subsidized feed.

\footnotetext{
23 In our survey, following Janssen and Swinnen (2019), we distinguished among four different types of concentrate feed: a) grains and grain bran; b) oilseeds and oilcakes; c) mixed concentrated feed; and d) other concentrates, which includes salts and mineral mixtures. While grains, oilseeds/oilcakes, and salts/mineral mixtures are all part of a balanced diet, the mixed concentrates usually contain all these elements and are therefore the best indicator of whether a dairy farm has adopted enhanced feeding practices. In Punjab, different types of mixed concentrated feed can be found: First, branded pre-mixed feed with different compositions that are combined in such way that fulfill the requirements of different types of animals (cross-bred/desi) as well as match the status of the DA (pregnant, in milk, dry) can be purchased (if available). Second, there is unbranded pre-mixed feed with varying composition. The survey data does not allow us to distinguish between these two types of concentrated feed, so they are both classified as mixed feed. Finally, some dairy farmers also mix their own concentrates, although this is done by only a small minority in our sample.
} 
However, our farm-level data present a different picture: Most of the dairy farms in both $2008(28.6 \%)$ and $2015(48.8 \%)$ indicated that the general store was the primary place for purchasing mixed feed. In 2015, only $2.1 \%$ and $2.5 \%$ of the farmers bought mixed feed from private companies and cooperatives respectively, which is even lower than in 2008.

Apart from enhancing the availability of mixed feed, companies can assist in increasing yields by informing dairy farms of the benefits of feed practices and training them in using proper quantities and ratios. Although there was a substantial increase in the number of dairy farms that were exposed to information on the importance of feed for milk quality, most received such information from other farms $(14.9 \%)$, the government $(3.9 \%)$ or veterinary doctors $(10.1 \%)$. Less than $1 \%$ of farmers received any advice or training that was related to animal feed from both private companies or cooperatives in both 2008 and 2015 (see Table 4 Panel B).

Finally, in Punjab, some milk buyers, both informal and formal ones, provide advance payments on milk. ${ }^{24}$ These advances can be used by the dairy farm for any purpose, including the purchase of improved feed. In 2008, $11.3 \%$ of the farmers received advances, but only $2.7 \%$ used them to buy inputs (medicines, fodder, improved feed, AI, etc.). In 2015, this increased to $17.7 \%$ of dairy farmers who received advances and $4.8 \%$ of them who used these advances to purchase inputs.

In summary, the use of mixed feed increased from $53.3 \%$ to almost $70 \%$ between 2008 and 2015. This is a substantial improvement, but still leaves room for increasing productivity through better feed. Although dairy companies claimed that they were increasingly providing such feed to their farmers, often at subsidized prices, according to our survey, very few small farmers bought or used mixed feed from the companies. In addition, there was virtually no

\footnotetext{
${ }^{24}$ Note that the provision of monetary funds in formal value chains is not provided by the processing firm themselves but rather by the managers of the collection centers who act like money lenders.
} 
training or information that was offered by the dairy companies on the potential benefits of (better) mixed feed.

\subsection{Technology adoption 3: cross-bred cows}

Punjab is one of the most important cross-bred cow breeding states in India. According to the latest official census in 2012, 27.6\% of the total bovine population in Punjab were cross-bred cows. Our survey data shows slightly higher number: $30.5 \%$ of total sample population consisted of cross-bred cows in 2008 and $39.2 \%$ in 2015. Although the total number of DA in our sample decreased from 2008 to 2015 , cross-bred cow numbers increased by almost $13 \%$ in this period (see Table 5).

In $2015,49.6 \%$ of the dairy farms indicated owning cross-bred cows, compared to $39.8 \%$ in 2008 (see Table 4 Panel C). Figure 11a shows the increase in the share of cross-bred cows and convergences across dairy farms from 2008 to 2015. In 2015, dairy farms had on average $29 \%$ of cross-bred cows in their total herd, which is a $45 \%$ change from 2008 (Figure 11b). This significant increase was largely driven by those dairy farms who had $0 \%$ to $50 \%$ of cross-bred share in 2008. Figure 12 also shows that the increase in the mean share of cross-bred cows took place across all marketing channels.

Yet again, the role of value chains in stimulating the adoption of more productive animal breeds appears to be limited. While in $2015,30.7 \%$ of the dairy farmers indicated receiving information on the benefits of choice of breed, almost none of them indicated that their milk buyer was the source. Both in 2008 and in 2015, less than $1 \%$ of farmers received information on the choice of breed from Nestlé and cooperatives. Again, most farmers cited other farmers, the government, and veterinary doctors as providers of such information. Investing in better animals with the help of value chain finance was absent in both 2008 and in 2015 . Very few farmers used a loan to finance the purchase of a cross-bred cow $(0.9 \%$ in 2008 , and $3.9 \%$ in 2015) and none of these loans were provided by value chains. 


\subsection{Technology adoption and value chain:}

There are several key conclusions from this descriptive evidence: First, there is an important increase in technology adoption level between 2008 and 2015 by the farmers in our survey:

(a) Hygienic practices improved significantly in 2015 compared to 2008, with scores on the hygiene index increasing on average from 0.53 to 0.70 : an improvement of $31 \%$.

(b) The use of mixed feed increased from $53.3 \%$ in 2008 to $68.8 \%$ in 2015 .

(c) The percentage of farmers who owned cross-bred DA increased from $39.8 \%$ in 2008 to $49.6 \%$ percent in 2015 .

Second, the increase in the average technology is mostly due to improvements in technology adoption by the slow adopters in 2008 , and much less due to further increases by farms that had already relatively high levels in 2008. In other words, there was convergence amongst dairy farms in technology adoption between 2008 and 2015.

Third, during interviews in both rounds of the survey, dairy companies in Punjab claimed that they actively supported better technology adoption at the farms. However, our farm-level data show that this was not the case among traditional dairy farms, except for the largest farmers. For all technologies, vertical coordination in the value chains seems to have played a minor role in promoting hygienic practices, fostering the use of mixed feed, or encouraging the purchase of higher yielding DA. Similarly, although more farmers received information with regard to the benefits of all three technologies in 2015 compared to 2008, farmers indicated that this information was mostly coming from other farmers, the government, and veterinary doctors— — not from dairy companies.

Fourth, the share of FDI (Nestlé) in sourcing fell significantly between 2008 and 2015. In its relationship with farmers there seems little difference between Nestlé and domestic dairy processing companies. 


\section{Econometric Analysis}

To explore further the relationship between technology adoption and specific value chains, we turn to econometric analysis. Previous studies in this area mostly rely on cross-sectional data, which makes it methodologically challenging to establish a causal relation between specific value chains and technology adoption due to various self-selection and endogeneity issues. Our panel data set allows us to address some of these caveats. As dependent variables, we use three technology adoption indicators: (1) an index of good hygienic practices; (2) a dummy that indicates the use of mixed feed; and (3) the share of cross-bred cows in total herd size.

We estimate Fixed Effects ${ }^{25}$ (FE) models for our two continuous adoption indicators (the index of good hygienic practices and the share of cross-bred cows in total herd size) and a Linear Probability Model $^{26}$ with Fixed Effects (LPM FE) for our binary adoption indicator (use of mixed feed), and thereby reduce potential bias stemming from time-invariant unobserved heterogeneity. It is important to note that the FE estimator can still suffer from endogeneity bias when unobservable time-variant factors are correlated with both technology adoption and buyer choice or when reverse-causality is driving the relationship.

The FE model is specified as follows:

$$
\mathrm{y}_{\mathrm{i}, \mathrm{t}}=\alpha_{i}+\beta \mathrm{C}_{\mathrm{i}, \mathrm{t}}+\gamma \mathrm{HS}_{\mathrm{i}, \mathrm{t}}+\theta \mathrm{X}_{\mathrm{i}, \mathrm{t}}+\mathrm{Y}_{\mathrm{t}}+\varepsilon_{\mathrm{i}, \mathrm{t}}
$$

\footnotetext{
${ }^{25}$ To verify that the Fixed Effects model is appropriate, we conduct the following steps: First we perform a Hausman test to decide between a FE and a Random Effects (RE) model. Next, we check if the assumption of strict exogeneity of explanatory variables holds by comparing outcomes of FE and first difference estimators (FD). The two estimators yield similar results, which means that explanatory variables do not correlate with past, current and future error terms. In short, the results showed that the FE model is preferred for studying both the adoption of improved hygienic practices and of cross-bred cows. The different models are presented in Tables A2 and A3 in the Appendix.

${ }^{26}$ There exists no consensus on the econometric technique that should be used to estimate a model with a binary dependent variable in a panel setting. We follow Angrist and Pischke (2009) in using a Linear Probability Model. The LPM offers econometric advantages over a logit model when running estimations on panel data as using a logit model in this setting will give rise to the incidental parameter problem and lead to inconsistent parameter estimation, especially when $\mathrm{T}$ is small. However, as a robustness check, we estimate: i) a probit model with FE and ii) a correlated random effects probit model that was proposed by Mundlak (1978). This correlated random effects model relaxes the strong assumption of RE models that time-invariant unobserved heterogeneity is not correlated with the independent variables. Concretely, time averages of the time-varying explanatory variables are added for each dairy farm as a set of controls. As such, we are estimating the effect of changes in the time-varying explanatory variables while keeping the time average fixed (Wooldridge, 2004). The results for all three models are similar and can be found in the appendix Table A4.
} 
where: $\mathrm{y}_{\mathrm{i}, \mathrm{t}}$ is the technology adoption indicator for dairy farms $\mathrm{i}$ at time $\mathrm{t}, \alpha_{i}$ is the individual dairy farm intercept; $\mathrm{C}_{\mathrm{i}, \mathrm{t}}$ is a set of marketing channel dummy variables; $\mathrm{HS}_{\mathrm{i}, \mathrm{t}}$ is a vector of variables related to farm size and income; $X_{i, t}$ is a vector of other socioeconomic farm household characteristics; $Y_{t}$ is a year dummy (taking the value of one for 2015); and $\varepsilon_{i, t}$ is the error term. The summary statistics of the variables in the regressions can be found in Table 6 .

First, the vector with marketing channel dummies was added to assess the primary objective of this paper: the impact of specific value chains on technology adoption including FDI (Nestlé). More specifically, the dummy variables capture the effect of switching to a specific value chain on technology adoption. $\mathrm{HS}_{\mathrm{i}, \mathrm{t}}$ also comprises of herd size as we expect farmers who expanded their herd sizes to be more likely to have adopted new technologies. Furthermore, it also includes physical capital in the form of land owned (in acres) and an index that captures non-land asset ownership. Both asset-types may reflect the capacity of dairy farms to invest in improved technologies. $\mathrm{HS}_{\mathrm{i}, \mathrm{t}}$ also includes the share of dairy income in total income as dairy farms that have an increased dependency on dairy may be more inclined to invest in new technologies

Furthermore, we include a control vector with time-variant farm household variables $\mathrm{X}_{\mathrm{i}, \mathrm{t}}$ that may influence technology adoption. We control for human capital by including age, gender and education of the household head as well as household size. Since anecdotal evidence from our fieldwork suggests that the task of taking care of the DA is often assigned to the women and elderly in the household, we also control for the number of household members over 55 as well as the number of female adults. Additionally, we include a dummy variable that indicates whether the household head changed between 2008 and 2015, so as to capture the effect of potential changes in the management of dairy activities. Finally, we include the year dummy variable $Y_{t}$, to capture all temporal variation in Punjab between 2008 and 2015, such 
as weather shocks and price variations. To deal with serial correlation and heteroscedasticity, we use robust standard errors and cluster them at the dairy-farm level.

The results for all three technology adoption indicators are presented in Table 7. Most importantly, the econometric analysis confirms what our descriptive statistics suggested (as summarized in Section 5.7). We find no effect of switching value chains on technology adoption indicators. Despite continued growth in the demand for milk products, value chains (still) do not appear to play a major role in stimulating technology adoption at the farm-level. This holds both for domestic and FDI companies.

Interestingly, a unit increase in the total number of DA has a significant and positive impact on both the probability of the use of mixed feed and the share of cross-bred cows, but not on the adoption of improved hygienic practices. One explanation is that the adoption of improved feed and of cross-bred cows requires additional investment compared to the adoption of improved hygienic practices and is therefore more strongly related with herd size expansion and commercialization.

\section{Growing Modern Dairy Farms and Integration in Value Chains}

As was explained above, the analysis in sections 5 and 6 is based on a random panel sample of dairy farmers in rural Punjab. However, during the 2015 surveys, we received information on the emergence of a group of new and larger commercial dairy farmers. We suspected that these farms would not be (sufficiently) captured by our surveys due to several reasons.

First, the majority of the milk producers in Punjab are very small, and each of these small producers owns only one or two DA (Vandeplas et al., 2013). Random sampling would thus lead to a sample with predominantly small farmers. We tried to overcome this through the use of a stratified random sampling strategy that allowed for the oversampling of large farmers (defined as owning more than 10 DA) (see section 4). However, the probability of capturing the very large farms in the survey remains low. 
Second, an important share of these new large dairy farms is located in the vicinity of urban areas. Because our survey was designed to represent the rural population of Punjab, the survey did not (sufficiently) capture the farmers that were located in these areas close to the cities.

Third, our panel survey includes household-farms that were already living and operating in rural areas in Punjab in 2008. Many of these modern dairy farms were established fairly recently, often after 2008, led by young professionals (like engineers and computer scientists) who consider commercial dairy farming as an interesting business opportunity, since demand is growing.

Not only are these new farms quite different from the ones captured in the survey, but ad hoc evidence suggests also that they represent an increasingly important share of Punjab dairy production. This is also consistent with a comparison of production indicators in the official statistics of the total Punjab dairy sector and in our sample. Total production in our sample declined slightly (-6\%) over the 2008-2015 period, while according to official statistics, total milk production in Punjab increased by $11.5 \%$ (Figure 1). This gap is most likely (at least partly) due to the growing share of production in these new large farms.

To obtain a better perspective on this emerging new part of the dairy chain, in addition to the small dairy farm surveys, we conducted a series of unstructured interviews with 11 of these large commercial farmers.

They represent a mixture of histories and location: Four of the 11 farms were established since 2008; five were located close to urban areas; and two were existing rural dairy farms that grew strongly in size between 2008 and 2015. The information from these interviews is not necessarily representative, but is relevant since it provides important additional insights into a dynamic new segment of the Punjab dairy sector that was not captured by our survey.

In the discussion below we refer to these farms as "modern dairy farms". Table 8 summarizes the key characteristics of these modern farms, and Table 9 summarizes the same 
characteristics for the 24 largest farmers in our survey: the farms that owned more than $10 \mathrm{DA}$ in 2015.

Almost all modern dairy farms (10 out of 11) and large sampled farmers (20 out of 24) were selling their milk to formal buyers, and none on the basis of a procurement contract. However, in many other ways, these two groups were very different. The modern dairy farms were much larger, and technology adoption was much more advanced. Herd sizes of modern dairy farms ranged from 70 DA to 165 DA, with an average of 114 DA, while herd sizes of the large sampled farmers were smaller and ranged from 11 DA to 96 DA, with an average of 19 DA. Modern dairy farms had virtually only cross-bred cows (on average 96\%), while herds of large sampled farmers on average were $60 \%$ cross-bred cows in 2015 . Modern dairy farms had 41 acres of land on average, which was considerably more than the 12 acres of large sampled farmers. Almost all modern dairy farms (10 out of 11) had mechanized milking, while only 6 out of 24 of the large sampled farmers had milking machines.

The level of interaction with dairy processors was also very different: Dairy processors often approached modern dairy farms and offered certain services, of which almost none were offered to the large sampled farmers. One such service was the picking-up of milk directly from the farmer or even the installation of a bulk milk cooler (BMC) on the farm, which is important for milk quality. All modern dairy farms indicated that their buyer picked up the milk from their farm, while only 6 out of 24 large sampled farmers reported that they received this service. The modern dairy farms also indicated that representatives of their milk buyer visited their farm regularly and provided information that was related to a broad range of topics, including issues that were related to veterinary care, government schemes, dairy technology, etc. However, only four $(16.7 \%)$ large sampled farmers stated that their milk buyers provided them with dairy related information. The majority of the modern dairy farms received assistance from dairy companies to invest in dairy equipment — such as like milking machines or feeding computers to better balance feed ratios. Dairy companies, both domestic and FDI, not only helped put 
modern dairy farms in contact with companies that were selling this equipment, but in certain cases they also offered interest free loans as part of a contract. The loans were repaid in instalments that were deducted from the milk payments. In contrast, none of the large sampled farmers received support for the purchase of dairy equipment. Dairy companies assisted modern dairy farms in their search for quality cross-bred cows, and in some cases, facilitated bank loans for herd extensions. While companies told us during interviews that they facilitated bank loans for farmers with all herd sizes, we only found evidence of this practice only for modern dairy farms.

In summary, this comparison — based on interviews with modern dairy farms — suggests that in addition to the rural farm sector that is captured by our sample, there is a different and more dynamic part of the Punjab milk production system. It consists of farms that are: considerably larger; fully commercial; using only modern technology (cross-bred cows and milk machines); and receiving extensive assistance in their management from the dairy companies (including loans for investments). They are part of much more integrated and vertically coordinated value chains than the value chains of the traditional dairy sector. Also in this industry segment, there appears to be little difference between domestic and foreign company strategies.

\section{Conclusions}

Adoption of modern technologies in agriculture can be crucial for improving the productivity and welfare of poor farmers in developing countries. Value chains can play a crucial role in fostering the adoption of new technology: by spreading information, and by supporting the modernization of procurement systems. While this process has been analyzed in emerging countries and in high-value supply chains in developing countries, little is known about how value chains do (not) affect technology transfer and/or adoption in domestic food chains in developing countries. 
In this paper we analyzed the impact of value chains on farm-level technology adoption in the dairy chain in India. Dairy products are a major part of Indian diets and milk production is a major production activity for many poor Indian farmers. There has been strong growth in dairy production and consumption in India over the past two decades. Our analysis relies on unique two-round small dairy farm survey data and company interviews from 2008 and 2015 in Punjab: one of the most rapidly expanding and dairy-developed regions in India.

First, we find that in the smallholder dairy sector in Punjab there was an impressive increase in adoption of all three important technology indicators between 2008 and 2015. Hygienic practices improved significantly by 2015, with scores on our hygienic index increasing on average by $31 \%$ : from 0.53 in 2008 to 0.70 in 2015 . The use of mixed feed increased from $53.3 \%$ in 2008 to $68.8 \%$ in 2015 . Finally, the percentage of farmers who owned cross-bred DA increased from $39.8 \%$ in 2008 to $49.6 \%$ in 2015 , while the share of cross-bred cows small dairy farms had in their total herd increased to 29\%: a 45\% change from 2008.

Second, there has been convergence amongst small dairy farms in technology adoption between 2008 and 2015. The improvement in the average technology is mostly due to improvements in technology adoption by slow adopters in 2008 , and much less due to the further increase by the farms that had already relatively high levels in 2008 .

Third, despite companies' reporting that they provided information and other support for technology adoption by small farmers, dairy companies (still) do not appear to play a major role in stimulating technology adoption for all farms in our sample. In both rounds of the survey, hardly any information on hygienic practices was provided by dairy companies. Further, there were fewer farm-level inspections in 2015; fewer small dairy farms sourced mixed feed from value chains in 2015 than in 2008; and no loans were provided by dairy companies for purchasing better breeds.

However, our study identified another, rapidly growing, more dynamic part of the Punjab dairy sector that is modern and much better integrated in vertically coordinated value 
chains. A group of modern and fully commercial dairy farms has emerged and grown over the past decade — often led by younger entrepreneurs and closer to urban areas. These modern farms use only modern technology (cross-bred cows and milk machines) and receive extensive assistance in their management from the dairy companies (including loans for investments). They are part of a much more integrated and vertically coordinated part of the dairy value chain than the traditional dairy sector. The information on this modern part of the value chain was based on non-representative interviews, so there is considerable room to improve the understanding of these dynamics by more representative methodologies.

In summary, our study identified two parts of the Punjab dairy system that are evolving quite differently: One part consists of the more traditional dairy farms. Our survey shows that there is considerable improvement in technology adoption in these traditional dairy farms and especially those who lagged in 2008 have improved their technology use. However, none of these improvements have resulted from vertical coordination in value chains, and there is much room for further technology adoption. The second part is a dynamic development of modern dairy farms that are much larger and more commercial and that use only modern technology. These farms are assisted by dairy companies in their management and investments and are fully integrated in vertically coordinated value chains. Finally, we find no significant difference in the operation and value chains of domestic and foreign dairy processing companies. 


\section{APPENDIX}

Table A1. Main channels of milk sales in Punjab for dairy farms that had DA in both 2008 and 2015

\begin{tabular}{|c|c|c|}
\hline 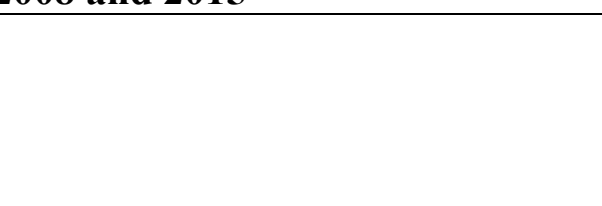 & $\begin{array}{c}\text { In } \mathbf{2 0 0 8} \\
\% \text { of dairy farmers in } \\
\text { sample } \\
(\mathrm{N}=633)\end{array}$ & $\begin{array}{c}\text { In } \mathbf{2 0 1 5} \\
\% \text { of dairy farmers in } \\
\text { sample } \\
(\mathrm{N}=633)\end{array}$ \\
\hline A. Cooperative & $22.9 \%$ & $19.6 \%$ \\
\hline B. Private companies & $39.7 \%$ & $27.2 \%$ \\
\hline Including: domestic companies & $14.8 \%$ & $13.0 \%$ \\
\hline foreign (Nestlé) & $24.8 \%$ & $14.2 \%$ \\
\hline C. Informal channels & $13.3 \%$ & $25.9 \%$ \\
\hline Including: households & $2.2 \%$ & $10.0 \%$ \\
\hline informal milk traders & $11.1 \%$ & $16.0 \%$ \\
\hline D. No Sales & $24.2 \%$ & $27.3 \%$ \\
\hline
\end{tabular}

Source: Survey data 
Table A2. Hygiene index, different models.

\begin{tabular}{|c|c|c|c|c|}
\hline & $\begin{array}{l}\text { POLS } \\
(1) \\
\end{array}$ & $\begin{array}{l}\mathrm{FE} \\
(2) \\
\end{array}$ & $\begin{array}{l}\text { FD } \\
(3) \\
\end{array}$ & $\begin{array}{l}\mathrm{RE} \\
(4) \\
\end{array}$ \\
\hline \multicolumn{5}{|c|}{ Supply chain: dairy farm switched to } \\
\hline Nestlé & $\begin{array}{c}0.0088 \\
(0.0296)\end{array}$ & $\begin{array}{l}-0.0008 \\
(0.0491)\end{array}$ & $\begin{array}{l}-0.0008 \\
(0.0378)\end{array}$ & $\begin{array}{c}0.0088 \\
(0.0296)\end{array}$ \\
\hline Cooperative & $\begin{array}{c}-0.0470 * * \\
(0.0189)\end{array}$ & $\begin{array}{l}-0.0317 \\
(0.0267)\end{array}$ & $\begin{array}{l}-0.0317 \\
(0.0262)\end{array}$ & $\begin{array}{c}-0.0470 * * \\
(0.0188)\end{array}$ \\
\hline Private domestic firm & $\begin{array}{c}-0.0493 * * \\
(0.0204)\end{array}$ & $\begin{array}{l}-0.0319 \\
(0.0286)\end{array}$ & $\begin{array}{l}-0.0319 \\
(0.0289)\end{array}$ & $\begin{array}{c}-0.0493 * * \\
(0.0204)\end{array}$ \\
\hline Informal milk traders & $\begin{array}{l}-0.0104 \\
(0.0148)\end{array}$ & $\begin{array}{l}-0.0086 \\
(0.0225)\end{array}$ & $\begin{array}{l}-0.0086 \\
(0.0240)\end{array}$ & $\begin{array}{l}-0.0104 \\
(0.0149)\end{array}$ \\
\hline Informally to households & $\begin{array}{c}-0.0435 * * * \\
(0.0165)\end{array}$ & $\begin{array}{l}-0.0233 \\
(0.0243)\end{array}$ & $\begin{array}{l}-0.0233 \\
(0.0272)\end{array}$ & $\begin{array}{c}-0.0435 * * * \\
(0.0165)\end{array}$ \\
\hline \multicolumn{5}{|l|}{ Farm size and income } \\
\hline Land & $\begin{array}{c}0.0272 * * * \\
(0.0052)\end{array}$ & $\begin{array}{l}0.0223 * \\
(0.0126)\end{array}$ & $\begin{array}{l}0.0223 * \\
(0.0131)\end{array}$ & $\begin{array}{c}0.0272 * * * \\
(0.0052)\end{array}$ \\
\hline Total No. of DA & $\begin{array}{l}0.0169^{*} \\
(0.0093)\end{array}$ & $\begin{array}{c}0.0292 \\
(0.0202)\end{array}$ & $\begin{array}{c}0.0292 \\
(0.0184)\end{array}$ & $\begin{array}{l}0.0169^{*} \\
(0.0097)\end{array}$ \\
\hline Asset index & $\begin{array}{c}-0.0259 * * * \\
(0.0056)\end{array}$ & $\begin{array}{c}-0.0394 * * * \\
(0.0099)\end{array}$ & $\begin{array}{c}-0.0394 * * * \\
(0.0100)\end{array}$ & $\begin{array}{c}-0.0259 * * * \\
(0.0055)\end{array}$ \\
\hline \multicolumn{5}{|l|}{ Farm-HH characteristics } \\
\hline Age $\mathrm{HH}$ head & $\begin{array}{c}0.0002 \\
(0.0003)\end{array}$ & $\begin{array}{l}-0.0001 \\
(0.0008)\end{array}$ & $\begin{array}{l}-0.0001 \\
(0.0010)\end{array}$ & $\begin{array}{c}0.0002 \\
(0.0003)\end{array}$ \\
\hline $\mathrm{HH}$ head is female & $\begin{array}{c}0.0189 \\
(0.0170)\end{array}$ & $\begin{array}{c}0.0507 \\
(0.0357)\end{array}$ & $\begin{array}{c}0.0507 \\
(0.0403)\end{array}$ & $\begin{array}{c}0.0189 \\
(0.0173)\end{array}$ \\
\hline HH head education & $\begin{array}{c}0.0004 \\
(0.0008)\end{array}$ & $\begin{array}{l}-0.0005 \\
(0.0012)\end{array}$ & $\begin{array}{l}-0.0005 \\
(0.0013)\end{array}$ & $\begin{array}{c}0.0004 \\
(0.0008)\end{array}$ \\
\hline HH size & $\begin{array}{c}0.0022 \\
(0.0021)\end{array}$ & $\begin{array}{l}-0.0034 \\
(0.0042)\end{array}$ & $\begin{array}{l}-0.0034 \\
(0.0042)\end{array}$ & $\begin{array}{c}0.0022 \\
(0.0021)\end{array}$ \\
\hline HH members over 55 & $\begin{array}{l}-0.0021 \\
(0.0043)\end{array}$ & $\begin{array}{l}-0.0087 \\
(0.0067)\end{array}$ & $\begin{array}{l}-0.00866 \\
(0.0070)\end{array}$ & $\begin{array}{l}-0.0021 \\
(0.0042)\end{array}$ \\
\hline No. of female adults in $\mathrm{HH}$ & $\begin{array}{c}0.0022 \\
(0.0047)\end{array}$ & $\begin{array}{c}0.0084 \\
(0.0073)\end{array}$ & $\begin{array}{c}0.0084 \\
(0.0073)\end{array}$ & $\begin{array}{c}0.0022 \\
(0.0048)\end{array}$ \\
\hline Year 2015 & $\begin{array}{c}0.178 * * * \\
(0.0095)\end{array}$ & $\begin{array}{c}0.185 * * * \\
(0.0128)\end{array}$ & $\begin{array}{c}0.185 * * * \\
(0.0134)\end{array}$ & $\begin{array}{c}0.178 * * * \\
(0.0095)\end{array}$ \\
\hline Change $\mathrm{HHH}$ & $\begin{array}{l}-0.0019 \\
(0.0159)\end{array}$ & $\begin{array}{l}-0.0282 \\
(0.0323)\end{array}$ & $\begin{array}{l}-0.0282 \\
(0.0357)\end{array}$ & $\begin{array}{c}-0.0019 \\
(0.0158)\end{array}$ \\
\hline Constant & $\begin{array}{l}0.264 * * * \\
(0.0236)\end{array}$ & $\begin{array}{l}0.292 * * * \\
(0.0532)\end{array}$ & & $\begin{array}{l}0.264 * * * \\
(0.0234)\end{array}$ \\
\hline $\begin{array}{l}\text { Observations } \\
\text { R-squared } \\
\text { Number of id }\end{array}$ & $\begin{array}{l}1,359 \\
0.299\end{array}$ & $\begin{array}{c}1,359 \\
0.457 \\
740 \\
\end{array}$ & $\begin{array}{c}619 \\
0.457\end{array}$ & $\begin{array}{c}1,359 \\
0.448 \\
740 \\
\end{array}$ \\
\hline
\end{tabular}

Note: Robust standard errors in parentheses*** $\mathrm{p}<0.01,{ }^{* *} \mathrm{p}<0.05,{ }^{*} \mathrm{p}<0.1$

Pooled OLS (POLS), Fixed effects (FE), First difference (FD), Random Effects (RE) 
Table A3. Share of cross-bred cows different models.

\begin{tabular}{|c|c|c|c|c|}
\hline & $\begin{array}{l}\text { POLS } \\
(1)\end{array}$ & $\begin{array}{l}\text { FE } \\
(2)\end{array}$ & $\begin{array}{l}\text { FD } \\
(3)\end{array}$ & $\begin{array}{l}\mathrm{RE} \\
(4)\end{array}$ \\
\hline \multicolumn{5}{|c|}{ Supply chain: dairy farm switched to } \\
\hline Nestlé & $\begin{array}{c}0.110^{*} \\
(0.0626)\end{array}$ & $\begin{array}{c}0.0108 \\
(0.0480)\end{array}$ & $\begin{array}{c}0.0108 \\
(0.0611)\end{array}$ & $\begin{array}{c}0.0576 \\
(0.0467)\end{array}$ \\
\hline Cooperative & $\begin{array}{c}0.0242 \\
(0.0424)\end{array}$ & $\begin{array}{c}0.0412 \\
(0.0444)\end{array}$ & $\begin{array}{c}0.0412 \\
(0.0419)\end{array}$ & $\begin{array}{c}0.0327 \\
(0.0388)\end{array}$ \\
\hline Private domestic firm & $\begin{array}{c}0.0246 \\
(0.0496)\end{array}$ & $\begin{array}{c}0.0555 \\
(0.0444)\end{array}$ & $\begin{array}{c}0.0555 \\
(0.0462)\end{array}$ & $\begin{array}{c}0.0490 \\
(0.0432)\end{array}$ \\
\hline Informal milk traders & $\begin{array}{l}-0.0469 \\
(0.0387)\end{array}$ & $\begin{array}{l}-0.0285 \\
(0.0382)\end{array}$ & $\begin{array}{l}-0.0285 \\
(0.0385)\end{array}$ & $\begin{array}{c}-0.0352 \\
(0.0338)\end{array}$ \\
\hline Informally to households & $\begin{array}{l}-0.0693 \\
(0.0445)\end{array}$ & $\begin{array}{l}-0.0525 \\
(0.0446)\end{array}$ & $\begin{array}{l}-0.0525 \\
(0.0442)\end{array}$ & $\begin{array}{c}-0.0634 \\
(0.0405)\end{array}$ \\
\hline \multicolumn{5}{|l|}{ Farm size and income } \\
\hline Land & $\begin{array}{c}-0.0700 * * * \\
(0.0127)\end{array}$ & $\begin{array}{c}-0.0078 \\
(0.0198)\end{array}$ & $\begin{array}{c}-0.0078 \\
(0.0211)\end{array}$ & $\begin{array}{c}-0.0548 * * * \\
(0.0126)\end{array}$ \\
\hline Total No. of DA & $\begin{array}{c}0.204 * * * \\
(0.0212)\end{array}$ & $\begin{array}{c}0.0924 * * * \\
(0.0300)\end{array}$ & $\begin{array}{c}0.0924 * * * \\
(0.0301)\end{array}$ & $\begin{array}{c}0.157 * * * \\
(0.0219)\end{array}$ \\
\hline Asset index & $\begin{array}{c}0.0175 \\
(0.0141) \\
\end{array}$ & $\begin{array}{l}0.00725 \\
(0.0163) \\
\end{array}$ & $\begin{array}{l}0.00725 \\
(0.0161) \\
\end{array}$ & $\begin{array}{c}0.0127 \\
(0.0131)\end{array}$ \\
\hline \multicolumn{5}{|l|}{ Farm-HH characteristics } \\
\hline Age $\mathrm{HH}$ head & $\begin{array}{c}0.0007 \\
(0.0008)\end{array}$ & $\begin{array}{c}0.0013 \\
(0.0015)\end{array}$ & $\begin{array}{c}0.0013 \\
(0.0016)\end{array}$ & $\begin{array}{c}0.0006 \\
(0.0008)\end{array}$ \\
\hline $\mathrm{HH}$ head is female & $\begin{array}{c}0.0356 \\
(0.0502)\end{array}$ & $\begin{array}{l}-0.113^{*} \\
(0.0602)\end{array}$ & $\begin{array}{l}-0.113 * \\
(0.0636)\end{array}$ & $\begin{array}{l}-0.0161 \\
(0.0496)\end{array}$ \\
\hline HH head education & $\begin{array}{c}0.0024 \\
(0.0019)\end{array}$ & $\begin{array}{c}0.0010 \\
(0.0021)\end{array}$ & $\begin{array}{c}0.0010 \\
(0.0021)\end{array}$ & $\begin{array}{c}0.0012 \\
(0.0018)\end{array}$ \\
\hline $\mathrm{HH}$ size & $\begin{array}{c}0.0037 \\
(0.0050)\end{array}$ & $\begin{array}{c}-0.0043 \\
(0.0069)\end{array}$ & $\begin{array}{c}-0.0043 \\
(0.0067)\end{array}$ & $\begin{array}{c}0.0023 \\
(0.0048)\end{array}$ \\
\hline HH members over 55 & $\begin{array}{c}-0.0061 \\
(0.0101)\end{array}$ & $\begin{array}{c}-0.0031 \\
(0.0105)\end{array}$ & $\begin{array}{c}-0.0031 \\
(0.0113)\end{array}$ & $\begin{array}{l}-0.0059 \\
(0.0091)\end{array}$ \\
\hline No. of female adults in $\mathrm{HH}$ & $\begin{array}{l}-0.0164 \\
(0.0110)\end{array}$ & $\begin{array}{l}-0.0146 \\
(0.0116)\end{array}$ & $\begin{array}{l}-0.0146 \\
(0.0118)\end{array}$ & $\begin{array}{l}-0.0153 \\
(0.0099)\end{array}$ \\
\hline Year 2015 & $\begin{array}{c}0.114 * * * \\
(0.0235)\end{array}$ & $\begin{array}{c}0.0857 * * * \\
(0.0207)\end{array}$ & $\begin{array}{c}0.0857 * * * \\
(0.0214)\end{array}$ & $\begin{array}{c}0.106 * * * \\
(0.0181)\end{array}$ \\
\hline Change HHH & $\begin{array}{c}0.0310 \\
(0.0462)\end{array}$ & $\begin{array}{c}0.0828 \\
(0.0528)\end{array}$ & $\begin{array}{c}0.0828 \\
(0.0576)\end{array}$ & $\begin{array}{c}0.0450 \\
(0.0425)\end{array}$ \\
\hline Constant & $\begin{array}{l}-0.115^{*} \\
(0.0595)\end{array}$ & $\begin{array}{l}-0.0030 \\
(0.0876)\end{array}$ & & $\begin{array}{l}-0.0425 \\
(0.0568)\end{array}$ \\
\hline $\begin{array}{l}\text { Observations } \\
\text { R-squared } \\
\text { Number of id }\end{array}$ & $\begin{array}{l}1,373 \\
0.104\end{array}$ & $\begin{array}{c}1,373 \\
0.110 \\
744\end{array}$ & $\begin{array}{c}629 \\
0.110\end{array}$ & $\begin{array}{c}1,373 \\
0.094 \\
744\end{array}$ \\
\hline
\end{tabular}

Note: Robust standard errors in parentheses $* * * p<0.01,{ }^{* *} \mathrm{p}<0.05,{ }^{*} \mathrm{p}<0.1$

Pooled OLS (POLS), Fixed effects (FE), First difference (FD), Random Effects (RE) 
Table A4. Use of mixed feed different models.

\begin{tabular}{|c|c|c|c|}
\hline & $\begin{array}{c}\text { LPM FE } \\
(1)\end{array}$ & $\begin{array}{l}\mathrm{FE} \\
(2) \\
\end{array}$ & $\begin{array}{l}\mathrm{CP} \\
(3) \\
\end{array}$ \\
\hline \multicolumn{4}{|c|}{ Supply chain: dairy farm switched to } \\
\hline Nestlé & $\begin{array}{l}0.0239 \\
(0.106)\end{array}$ & $\begin{array}{l}0.0239 \\
(0.105)\end{array}$ & $\begin{array}{c}0.0912 \\
(0.361)\end{array}$ \\
\hline Cooperative & $\begin{array}{c}0.0900 \\
(0.0850)\end{array}$ & $\begin{array}{c}0.0900 \\
(0.0842)\end{array}$ & $\begin{array}{c}0.225 \\
(0.258)\end{array}$ \\
\hline Private domestic firm & $\begin{array}{c}0.0818 \\
(0.0936)\end{array}$ & $\begin{array}{c}0.0818 \\
(0.0928)\end{array}$ & $\begin{array}{c}0.153 \\
(0.272)\end{array}$ \\
\hline Informal milk traders & $\begin{array}{c}0.0622 \\
(0.0748)\end{array}$ & $\begin{array}{c}0.0622 \\
(0.0742)\end{array}$ & $\begin{array}{c}0.109 \\
(0.224)\end{array}$ \\
\hline Informally to households & $\begin{array}{c}0.140 \\
(0.0870) \\
\end{array}$ & $\begin{array}{c}0.140 \\
(0.0863) \\
\end{array}$ & $\begin{array}{c}0.340 \\
(0.256) \\
\end{array}$ \\
\hline \multicolumn{4}{|l|}{ Farm size and income } \\
\hline Land & $\begin{array}{c}0.0382 \\
(0.0417)\end{array}$ & $\begin{array}{c}0.0382 \\
(0.0413)\end{array}$ & $\begin{array}{c}0.106 \\
(0.124)\end{array}$ \\
\hline Total No. of DA & $\begin{array}{c}0.293 * * * \\
(0.0413)\end{array}$ & $\begin{array}{c}0.293 * * * \\
(0.0410)\end{array}$ & $\begin{array}{c}1.049 * * * \\
(0.147)\end{array}$ \\
\hline Asset index & $\begin{array}{c}-0.0436 \\
(0.0326)\end{array}$ & $\begin{array}{c}-0.0436 \\
(0.0323)\end{array}$ & $\begin{array}{c}-0.127 \\
(0.0950)\end{array}$ \\
\hline \multicolumn{4}{|l|}{ Farm-HH characteristics } \\
\hline Age HH head & $\begin{array}{l}-0.0020 \\
(0.0024)\end{array}$ & $\begin{array}{l}-0.0020 \\
(0.0024)\end{array}$ & $\begin{array}{c}-0.0081 \\
(0.0082)\end{array}$ \\
\hline $\mathrm{HH}$ head is female & $\begin{array}{c}-0.0327 \\
(0.0978)\end{array}$ & $\begin{array}{c}-0.0327 \\
(0.0970)\end{array}$ & $\begin{array}{l}-0.100 \\
(0.322)\end{array}$ \\
\hline HH head education & $\begin{array}{c}-0.0023 \\
(0.0036)\end{array}$ & $\begin{array}{c}-0.0023 \\
(0.0035)\end{array}$ & $\begin{array}{c}-0.0093 \\
(0.0117)\end{array}$ \\
\hline HH size & $\begin{array}{c}0.0036 \\
(0.0126)\end{array}$ & $\begin{array}{c}0.0036 \\
(0.0125)\end{array}$ & $\begin{array}{c}0.0021 \\
(0.0380)\end{array}$ \\
\hline HH members over 55 & $\begin{array}{c}0.0037 \\
(0.0195)\end{array}$ & $\begin{array}{c}0.0037 \\
(0.0193)\end{array}$ & $\begin{array}{c}0.0082 \\
(0.0617)\end{array}$ \\
\hline No. of female adults in $\mathrm{HH}$ & $\begin{array}{c}0.0083 \\
(0.0215)\end{array}$ & $\begin{array}{c}0.0083 \\
(0.0213)\end{array}$ & $\begin{array}{c}0.0489 \\
(0.0670)\end{array}$ \\
\hline Year 2015 & $\begin{array}{c}0.135 * * * \\
(0.0314)\end{array}$ & $\begin{array}{c}0.135 * * * \\
(0.0312)\end{array}$ & $\begin{array}{c}0.502 * * * \\
(0.117)\end{array}$ \\
\hline Change $\mathrm{HHH}$ & $\begin{array}{c}-0.0375 \\
(0.0976)\end{array}$ & $\begin{array}{c}-0.0375 \\
(0.0968)\end{array}$ & $\begin{array}{l}-0.162 \\
(0.305)\end{array}$ \\
\hline Constant & $\begin{array}{c}-0.0260 \\
(0.148)\end{array}$ & $\begin{array}{c}-0.0260 \\
(0.147)\end{array}$ & $\begin{array}{c}-2.334 * * * \\
(0.311)\end{array}$ \\
\hline $\begin{array}{l}\text { Observations } \\
\text { R-squared } \\
\text { Number of id }\end{array}$ & $\begin{array}{c}1,718 \\
0.640 \\
866 \\
\end{array}$ & $\begin{array}{c}1,718 \\
0.099 \\
866 \\
\end{array}$ & 1,718 \\
\hline
\end{tabular}

Note: Robust standard errors in parentheses. $* * * \mathrm{p}<0.01,{ }^{* *} \mathrm{p}<0.05,{ }^{*} \mathrm{p}<0.1$

Robust standard errors in parentheses. CP: correlated random effects probit model.

Averages of independent variables in CP model were dropped from the table for space. 
Figure A1. Distribution of hygiene index in 2008 and 2015 in Punjab among the dairy farms that had DA in both year $(n=633)$

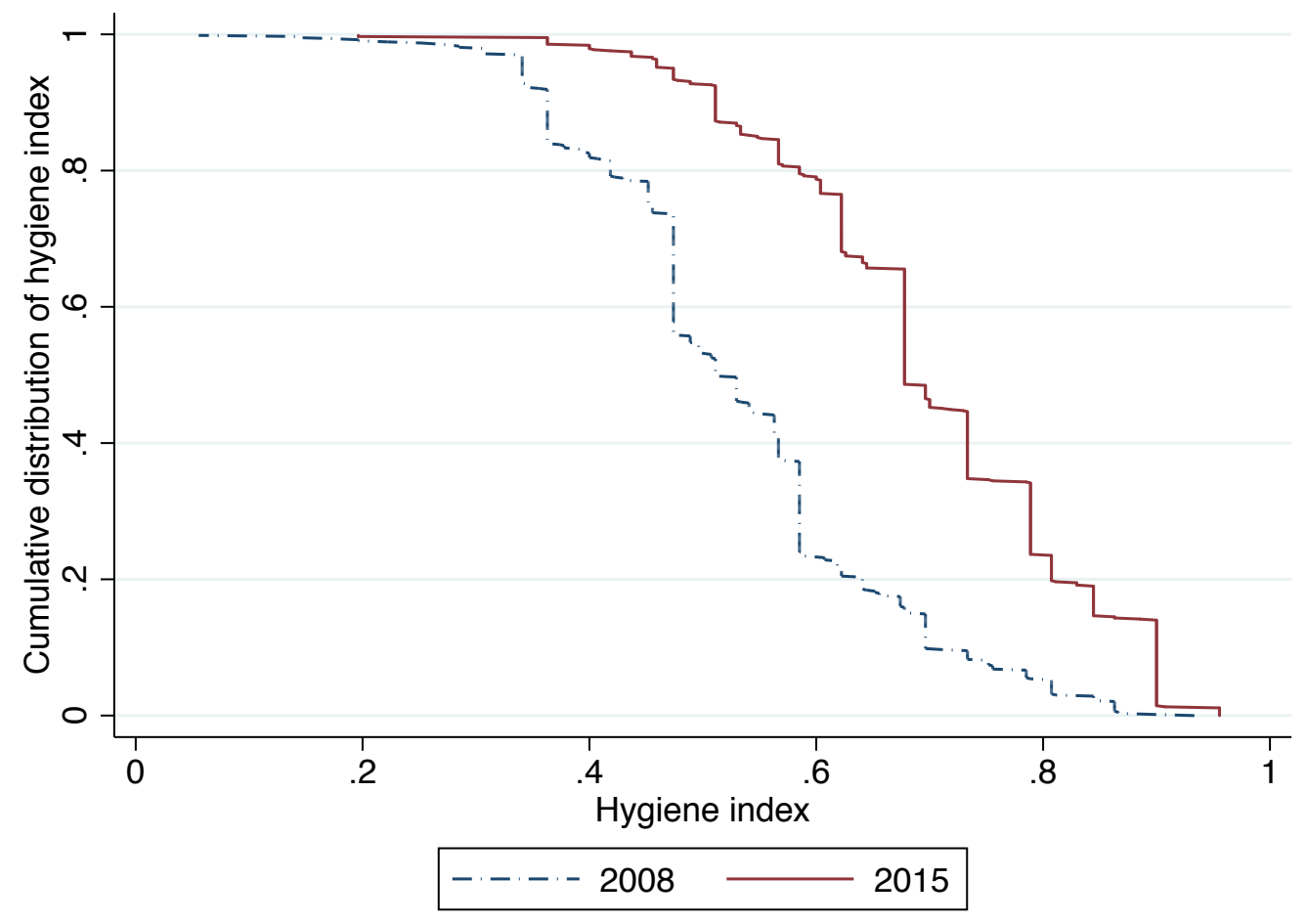

Source: Survey data

Figure A2. Hygiene index and milk marketing channels for dairy farms that had DA in both years $(n=633)$

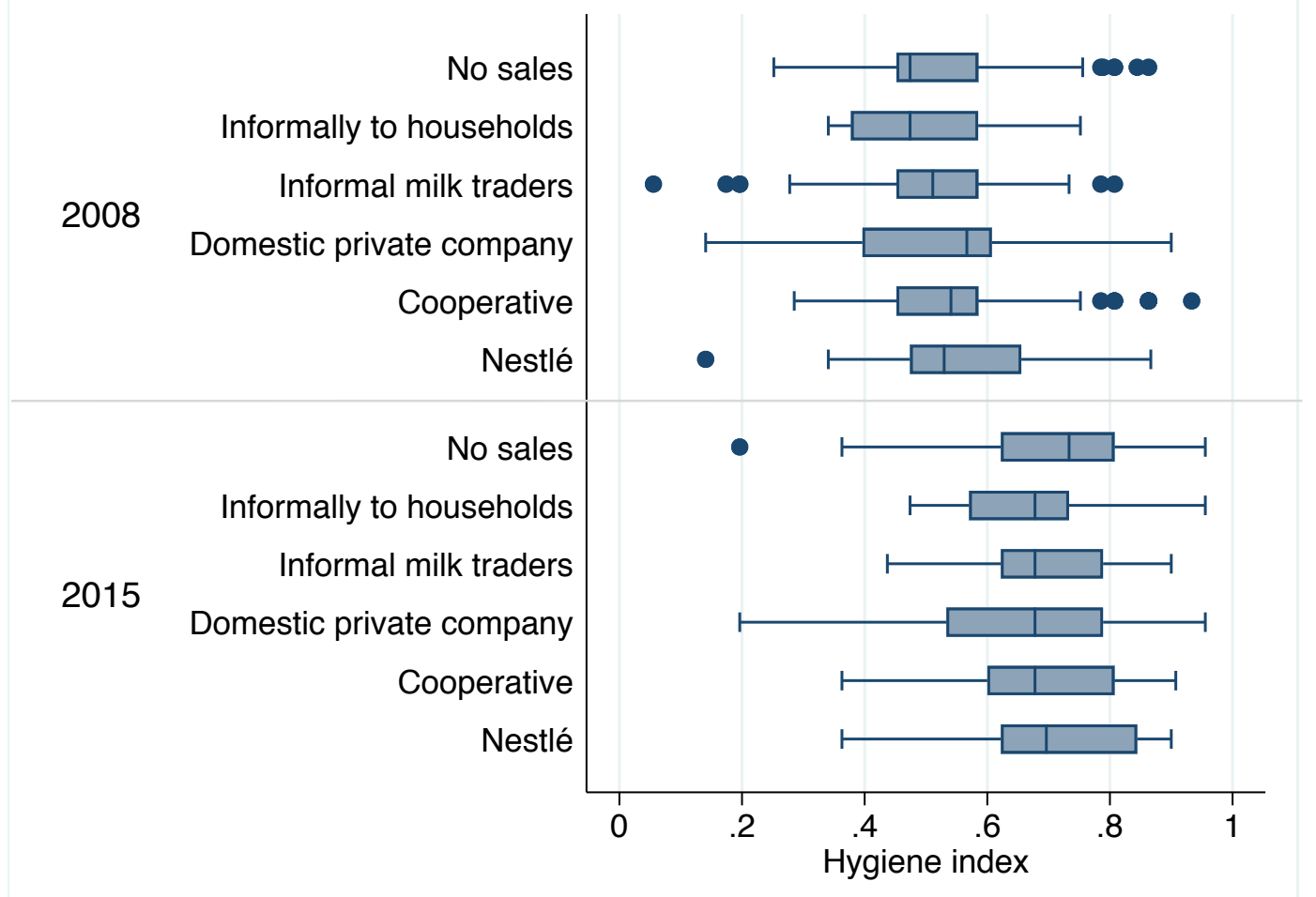

Source: Survey data 
Figure A3. Mixed feed use and milk marketing channels for dairy farms that had DA in both years $(n=633)$

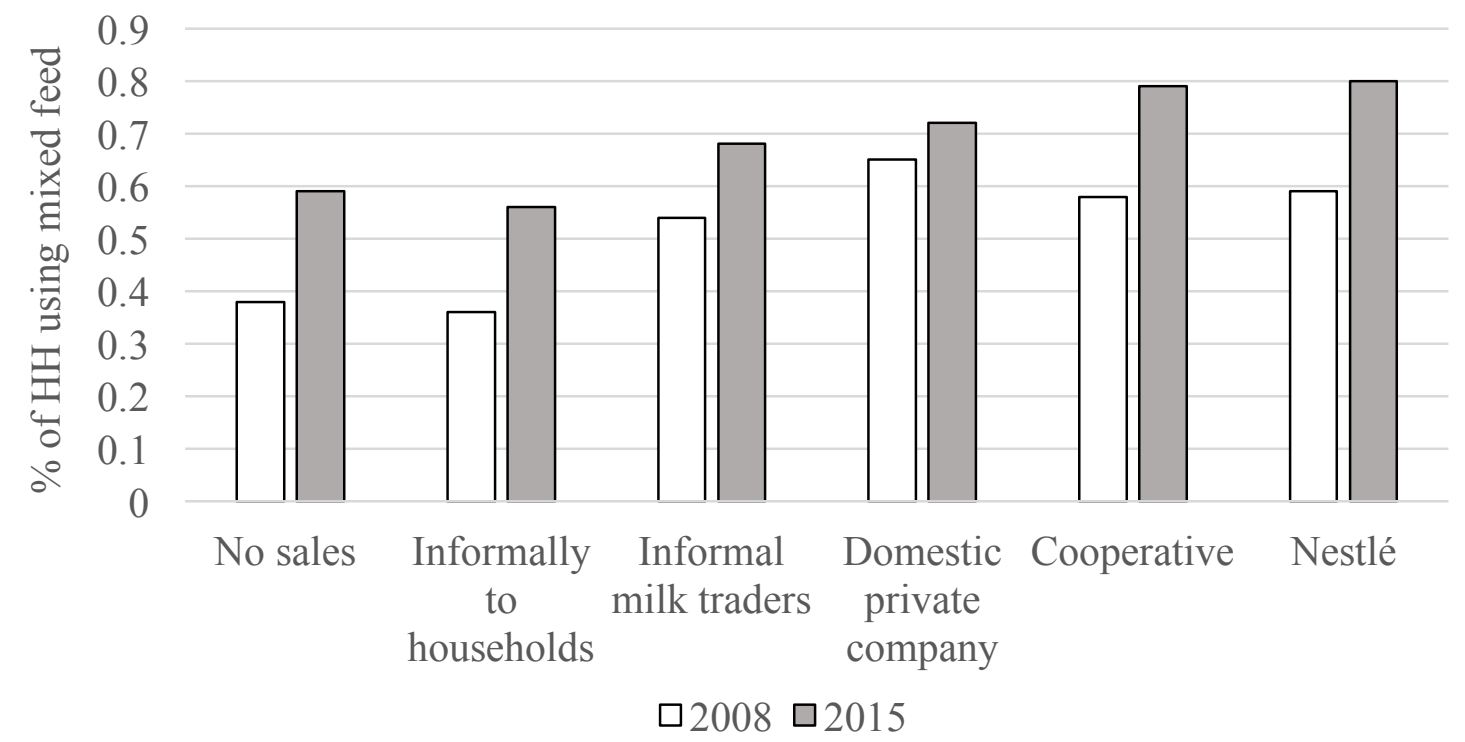

Source: Survey data

Figure A4. Share of cross-bred cows across marketing channels (means) for dairy farms that had DA in both years $(n=633)$

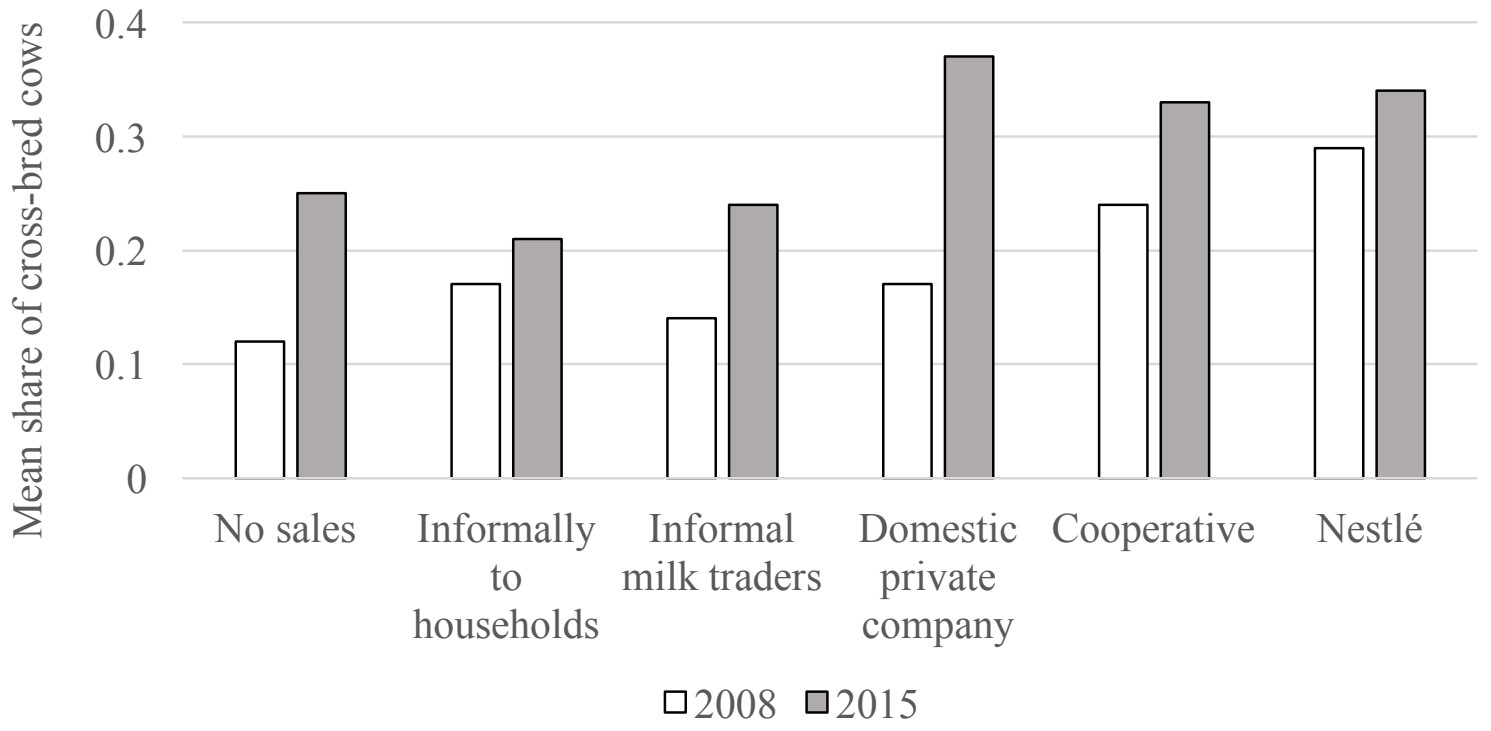

Source: Survey data 


\section{Acknowledgements}

This paper benefited from comments from conference participants in Montpellier (EAAE).

Research on this project was financially supported by the KU Leuven (Methusalem Program), the FWO Excellence of Science (EOS) Research program (WLG-Micro), and the EU Horizon 2020 RESPECT Project. 


\section{References}

Angrist, J. D., \& J. S. Pischke, (2009). Mostly Harmless Econometrics: An Empiricist's Companion. Princeton University Press.

Bandiera, O., \& Rasul, I. (2006). Social Networks and Technology Adoption in Northern Mozambique. The Economic Journal, 116(514), 869-902.

Banerjee, A. V., \& Duflo, E. (2014). Do Firms Want to Borrow More? Testing Credit Constraints Using a Directed Lending Program. The Review of Economic Studies, 81(2), 572607.

Bardhan, P., (1989). The Economic Theory of Agrarian Institutions Clarendon. Oxford University Press.

Bardhan, P., \& Udry, C. (1991). Development Microeconomics. Oxford University Press.

Barrett, C. B., Maren, E. B., Bellemare, M. F., Michelson, H. C., Narayanan, S. \& Walker, T. F. (2012). Smallholder Participation in Contract Farming: Comparative Evidence from Five Countries. World Development, 40(4), 715-30.

Bell, C., \& Srinivasan, T. N. (1989). Interlinked Transactions in Rural Markets: An Empirical Study of Andhra Pradesh, Bihar and Punjab. Oxford Bulletin of Economics and Statistics, 51(1), 73-83.

Bellemare, M. F. (2012). As You Sow, So Shall You Reap: The Welfare Impacts of Contract Farming. World Development, 40(7), 1418-1434.

Birthal, P.S., Chand, R., Joshi, P.K., Saxena, R., Rajkhowa, P., Khan, M.T., Khan, M.A. \& Chaudhary, K.R. (2017). Formal versus informal: Efficiency, inclusiveness and financing of dairy value chains in Indian Punjab. Journal of rural studies, 54, 288-303.

Birthal, P. S., \& Jha, A. K. (2005). Review on emerging trends in India's livestock economy: Implications for development policy. The Indian Journal of Animal Sciences, 75(10).

Bolwig, S., Gibbon, P. \& Jones, S. (2009). The Economics of Smallholder Organic Contract Farming in Tropical Africa. World Development, 37(6), 1094-1104.

CAG (2017). Performance Audit on Implementation of Food Safety and Standards Act. Report No.37 of 2017, Union Government.

Cameron, L. A., (1999). The Importance of Learning in the Adoption of High-yielding Variety Seeds. American Journal of Agricultural Economics, 81(1), 83-94.

Chand, R., (1999). Emerging crisis in Punjab agriculture: Severity and Options for future. Economic and Political Weekly, 34(13), A2-A10.

Conley, T. G., \& Udry, C. R. (2010). Learning About a New Technology: Pineapple in Ghana.” The American Economic Review, 100(1), 35-69.

Cungu, A., Gow, H., Swinnen, J. F. M. \& Vranken, L. (2008). Investment with Weak Contract Enforcement: Evidence from Hungary during Transition. European Review of Agricultural Economic, 35(1), 75-91. 
Cunningham, K., 2010. Rural and Urban Linkages: Operation Flood's Role in India's Dairy Development. IFPRI discussion paper 00924.

Dries, L., Germenji, E., Noev, N. \& Swinnen, J. F. M. (2009). Farmers, Vertical Coordination, and The Restructuring of Dairy Supply Chains in Central and Eastern Europe. World Development, 37(11), 1742-1758.

Dries, L., \& Swinnen, J. F. M. (2004). Foreign Direct Investment, Vertical Integration, and Local Suppliers: Evidence from the Polish Dairy Sector. World Development, 32(9), 15251544.

Evenson, R. E., \& Gollin, D. (2003). Assessing the Impact of the Green Revolution, 1960 to 2000. Science, 300(5620), 758-62.

FAO (2012). Balanced Feeding for Improving Livestock Productivity - Increase in Milk Production and Nutrient Use Efficiency and Decrease in Methane Emission, by M.R. Garg. FAO Animal Production and Health Paper No. 173. Rome, Italy.

FAO (2010). Status of and Prospects for Smallholder Milk Production-A Global Perspective, by T.Hemme and J. Otte. Rome.

FAOSTAT (2019). Available at: http://faostat.fao.org.

Feder, G., Just, R. E. \& Zilberman, D. (1985). Adoption of Agricultural Innovations in Developing Countries: A Survey. Economic development and cultural change, 33(2), 255-298.

Feder, G., \& Umali, D. (1993). The Adoption of Agricultural Innovations: A Review. Technological Forecasting and Social Change, 43(3-4), 215-239.

Genius, M., Koundouri, P., Nauges, C. \& Tzouvelekas, V. (2013). Information Transmission in Irrigation Technology Adoption and Diffusion: Social Learning, Extension Services and Spatial Effects. American Journal of Agricultural Economics, 96(1), 328-344.

Goswami, B., (2007). Can Indian Dairy Cooperatives Survive in the New Economic Order? Paper presented at the WTO Public Forum "How Can the WTO Help Harness Globalization", Geneva, Switzerland.

Gow, H. R., Streeter, D. H. \& Swinnen, J. F. M. (2000). How Private Contract Enforcement Mechanisms Can Succeed Where Public Institutions Fail: The Case of Juhocukor A.S. Agricultural Economics, 23(3), 253-265.

Gow, H. R., \& Swinnen, J. F. M. (2001). Private Enforcement Capital and Contract Enforcement in Transition Economies. American Journal of Agricultural Economics, 83(3), 686-90.

Janssen, E., \& Swinnen, J. F. M. (2019). Technology adoption and value chains in developing countries: Evidence from dairy in India. Food Policy, 83, 327-336.

Jha, B., (2003). India's Dairy Sector in the Emerging Trade Order. IEG Working Paper E/243/2004.

Jones, S., \& Gibbon, P. (2011). Developing Agricultural Markets in Sub-Saharan Africa: Organic Cocoa in Rural Uganda. Journal of Development Studies, 47(10), 1595-1618. 
Klein, B., Robert, G. C. \&. Alchian, A. A (1978). Vertical Integration, Appropriable Rents, and the Competitive Contracting Process. The Journal of Law and Economics, 21(2), 297-326.

Kuijpers, R., \& Swinnen, J. F. M. (2016). Value Chains and Technology Transfer to Agriculture in Developing and Emerging Economies. American Journal of Agricultural Economics, 98,1403-1418.

Kumar, A., Roy, D., Joshi, P. K., Tripathi, G. \& Adhikari, R. P. (2016). Impact of Contract Farming on Profits and Yield of Smallholder Farms in Nepal: An Evidence from Lentil Cultivation. Annual Meeting, July 31-August 2, 2016, Boston, Massachusetts. Agricultural and Applied Economics Association.

Kumar, A., Joshi, P. K., Kumar, P. \& Parappurathu S. (2014) Trends in the consumption of milk and milk products in India: implications for self-sufficiency in milk production. Food Security, 6(5), 719.

Kumar, A., Wright, I. A. \& Singh, D. K. (2011). Adoption of Food Safety Practices in Milk Production: Implications for Dairy Farmers in India. Journal of International Food \& Agribusiness Marketing, 23(4), 330-344.

Kumar, A., S. Parappurathu \& P. K. Joshi. (2013) Structural Transformation in Dairy Sector of India. Agricultural Economics Research Review, 26(2), 209-2019.

Maertens, M., Colen, L. \& Swinnen, J.F.M. (2011). Globalisation and Poverty in Senegal: A Worst Case Scenario? European Review of Agricultural Economics, 38(1), 31-54.

Maertens, M., \& Vande Velde, K. (2017). Contract-Farming in Staple Food Chains: The Case of Rice in Benin. World Development, 95, 73-87.

Maertens, M., \& Swinnen, J. F. M. (2009). Trade, Standards, and Poverty: Evidence from Senegal. World Development, 37(1), 161-178.

Minten, B., \& Reardon, T. (2008). Food Prices, Quality, and Quality's Pricing in Supermarkets vs Traditional Markets in Developing Countries. Review of Agricultural Economics, 30(3), 480490.

Minten, B., Reardon, T. \& Vandeplas, A. (2009). Linking Urban Consumers and Rural Farmers in India: A Comparison of Traditional and Modern Food Supply Chains. IFPRI discussion papers 883, International Food Policy Research Institute (IFPRI).

Minten, B., Tamru, S., Engida, E. \& Kuma, T. (2016). Transforming Staple Food Value Chains in Africa: The Case of Teff in Ethiopia. The Journal of Development Studies, 52(5), 627-645.

Mo, D., Huang, J., Jia, X., Luan, H., Rozelle, S. \& Swinnen, J. F. M. (2012). Checking into China's Cow Hotels: Have Policies Following the Milk Scandal Changed the Structure of the Dairy Sector? Journal of Dairy Science, 95(5), 2282-2298.

Mondal, B., Sirohi, S. \& Thorat, V. (2012). Impact of ASEAN-India Free Trade Agreement on Indian Dairy Trade: A Quantitative Approach. MPRA working paper 40790.

Moser, C. M., \& Barrett, C. B. (2006). The Complex Dynamics of Smallholder Technology Adoption: The Case of SRI in Madagascar. Agricultural Economics, 35(3), 373-388. 
Mundlak, Y., (1978). On the Pooling of Time Series and Cross Section Data. Econometrica, 46, 69-85.

Munshi, K., (2004). Social Learning in a Heterogeneous Population: Technology Diffusion in the Indian Green Revolution. Journal of Development Economics, 73(1), 185-213.

Nagrale, B. G., Datta, K. K. \& Chauhan, A. K. (2015). An Analysis of Constraints Faced by Dairy Farmers in Vidarbha Region of Maharashtra. Indian Journal of Dairy Science, 68(4), 390-394.

National Dairy Development Board, 2020. Statistics available at http://www.nddb.org/information/stats/milkprodindia. Accessed on 03/04/2017.

Rao, S. V. N., Venkatasubramanian, V. \& De Wit, J. (1995). Consequences of Crossbreeding Programme in India. Economic and Political Weekly, 30(39), A112-16.

Reardon, T., Barrett, C. B., Berdegue, J. A. \& Swinnen, J. F. M. (2009). Agrifood Industry Transformation and Small Farmers in Developing Countries. World Development, 37(11), $1717-1727$.

Reardon, T., \& Timmer, C. P. (2014). Five Inter-Linked Transformations in the Asian Agrifood Economy: Food Security Implications. Global Food Security, 3(2), 108-117.

Saenger, C., Maximo, T.\& Qaim, M. (2014). Impact of Third-Party Contract Enforcement in Agricultural Markets-A Field Experiment in Vietnam. American Journal of Agricultural Economics, 96(4), 1220-1238.

Sheahan, M., \& Barrett, C. B. (2014). Understanding the Agricultural Input Landscape in SubSaharan Africa: Recent Plot, Household, and Community-Level Evidence. The World Bank.

Sinha, B. N. (1951). Taylor Cows of Patna. Indian Veterinary Journal, 27, 272-276.

Squicciarini, M., \& Vandeplas, A. (2010). The Dairy Sector of Andhra Pradesh: Findings from a Company Survey. No. TAPSIM deliverable D5.3, LICOS, KU Leuven, Belgium.

Squicciarini, M., \& Vandeplas, A. (2013). Food Safety Standards for Domestic and International Markets: The Case of Dairy. In Brouwer, F., Joshi, P.K. (eds.) International trade and poverty; the future of Indian agriculture. Oxfordshire: CABI Publications.

Staal, S. J., Nin Pratt, A. \& Jabbar, M. (2008). Dairy Development for the Resource Poor. Part 3: Pakistan and India Dairy Development Case Studies. PPLPI Working paper No.44-3, International Livestock Research Institute and Food and Agriculture Organization of the United Nations.

Swinnen, J. F. M., Deconinck, K., Vandemoortele T.\& Vandeplas, A. (2015). Quality Standards, Value Chains and International Development. Cambridge University Press. New York, USA.

Swinnen, J., \& Kuijpers, R. (2019). Value chain innovations for technology transfer in developing and emerging economies: Conceptual issues, typology, and policy implications. Food Policy, 83, 298-309.

Swinnen, J. F., \& Vandeplas, A. (2010). Market power and rents in global supply chains. Agricultural Economics, 41, 109-120. 
Umali-Deininger, D., \& Sur, M., (2007). Food safety in a globalizing world: opportunities and challenges for India. Agricultural Economics, 37(s1), 135-147.

Vandeplas, A., Minten, B. \& Swinnen, J. F. M. (2013). Multinationals vs. Cooperatives: The Income and Efficiency Effects of Supply Chain Governance in India. Journal of Agricultural Economics, 64(1), 217-244.

Van Campenhout, B., Minten, B., \& Swinnen, J. (2019). Domestic versus export-led agricultural transformation: Evidence from Uganda's dairy value chain. IFPRI Discussion Paper 1883

Vandemoortele, T., Rozelle, S., Swinnen, J., \& Xiang, T. (2012). Quality and inclusion of producers in value chains: a theoretical note. Review of Development Economics, 16(1), 122136.

Van Herck, K., Swinnen, J. F. M. \& Deconinck, K. (2012). How the east was won: Supply chain restructuring in the Eastern European beer market. German Journal of Agricultural Economics, 61(670-2016-45941), 213-222.

Williamson, O. E. (1985). The Economic Institutions of Capitalism. Simon and Schuster.

Wooldridge, J. M., (2004). Econometric Analysis of Cross Section and Panel Data. The MIT Press. London, England.

World Bank (2005). The Dynamics of Vertical Coordination in Agrifood Chains in Eastern Europe and Central Asia. Washington, DC: World Bank.

Zilberman, D., Lu, L., \& Reardon, T. (2019). Innovation-induced food supply chain design. Food Policy, 83, 289-297. 
Table 1. Main channels of milk sales in Punjab for all dairy farmers in sample

\begin{tabular}{|c|c|c|}
\hline & $\begin{array}{c}\text { In } \mathbf{2 0 0 8} \\
\% \text { of dairy farmers in } \\
\text { sample } \\
(\mathrm{N}=710)\end{array}$ & $\begin{array}{c}\text { In } \mathbf{2 0 1 5} \\
\text { \% of dairy farmers in } \\
\text { sample } \\
(\mathrm{N}=676)\end{array}$ \\
\hline A. Cooperative & $22.1 \%$ & $18.5 \%$ \\
\hline B. Private companies & $38.9 \%$ & $26.9 \%$ \\
\hline Including: domestic companies & $14.2 \%$ & $12.6 \%$ \\
\hline foreign (Nestlé) & $24.7 \%$ & $14.4 \%$ \\
\hline C. Informal channels & $13.5 \%$ & $25.7 \%$ \\
\hline Including: households & $2.3 \%$ & $10.2 \%$ \\
\hline informal milk traders & $11.3 \%$ & $15.5 \%$ \\
\hline D. No Sales & $25.5 \%$ & $29.1 \%$ \\
\hline
\end{tabular}

Source: Survey data 
Table 2. Distribution of dairy farmers associated with different value chains (\%)

\begin{tabular}{lccccc|cccc}
\hline \multicolumn{1}{c}{ In 2008 (N=710) } \\
\hline
\end{tabular}

Note: Table includes only HH that had DA.

Source: Survey data 
Table 3. Hygienic and food safety practices in Punjab (\% of dairy farmers in sample)

\begin{tabular}{|c|c|c|}
\hline & $\begin{array}{l}\text { In } 2008 \\
(\mathrm{~N}=710)\end{array}$ & $\begin{array}{l}\text { In } 2015 \\
(\mathrm{~N}=671)\end{array}$ \\
\hline \multicolumn{3}{|l|}{ Hygienic practices } \\
\hline \multicolumn{3}{|l|}{ Cleaning hands } \\
\hline \multicolumn{3}{|l|}{ Are the hands washed? } \\
\hline Never & $2.8 \%$ & $0.5 \%$ \\
\hline Only before milking & $38.5 \%$ & $36.9 \%$ \\
\hline In between & $58.7 \%$ & $62.1 \%$ \\
\hline \multicolumn{3}{|l|}{ Mode of washing hands } \\
\hline No hand washing & $2.8 \%$ & $0.5 \%$ \\
\hline Water only & $83.6 \%$ & $42.7 \%$ \\
\hline Use soap/detergent/disinfectant & $13.5 \%$ & $56.8 \%$ \\
\hline \multicolumn{3}{|l|}{ Hands dried with paper/cloth before milking? } \\
\hline Yes & $25.5 \%$ & $66.4 \%$ \\
\hline \multicolumn{3}{|l|}{ Cleaning of udder and teats } \\
\hline \multicolumn{3}{|l|}{ Washed before milking? } \\
\hline No washing & $11.8 \%$ & $4.6 \%$ \\
\hline Water only & $83.9 \%$ & $90.2 \%$ \\
\hline Cold water+ soap/detergent/disinfectant & $3.4 \%$ & $5.4 \%$ \\
\hline \multicolumn{3}{|l|}{ Dried with paper /cloth before milking? } \\
\hline Yes & $14.2 \%$ & $23.4 \%$ \\
\hline \multicolumn{3}{|l|}{ Cleaning of milk utensils } \\
\hline \multicolumn{3}{|l|}{ How are milk utensils washed? } \\
\hline Water only & $80.4 \%$ & $14.1 \%$ \\
\hline Water + soap/detergent/disinfectant & $17.4 \%$ & $79.8 \%$ \\
\hline Water + sand + ash & $0 \%$ & $6.3 \%$ \\
\hline \multicolumn{3}{|l|}{ How often are the utensils washed? } \\
\hline Less than once daily & $3.1 \%$ & $0.14 \%$ \\
\hline Once daily & $20.4 \%$ & $1.6 \%$ \\
\hline More than once daily & $75.7 \%$ & $98.3 \%$ \\
\hline Before milking each new cow/buffalo & $0.14 \%$ & $0.14 \%$ \\
\hline \multicolumn{3}{|l|}{ Food safety practices } \\
\hline \multicolumn{3}{|l|}{ Method of milk preservation before sales } \\
\hline Not treated & $64.2 \%$ & $61.9 \%$ \\
\hline Boiling & $1.5 \%$ & $0.9 \%$ \\
\hline Refrigerating/chilling & $5.1 \%$ & $7.9 \%$ \\
\hline Other & $8.3 \%$ & $0.14 \%$ \\
\hline
\end{tabular}

Source: Survey data 
Table 4. Value chains, technology adoption and information in Punjab

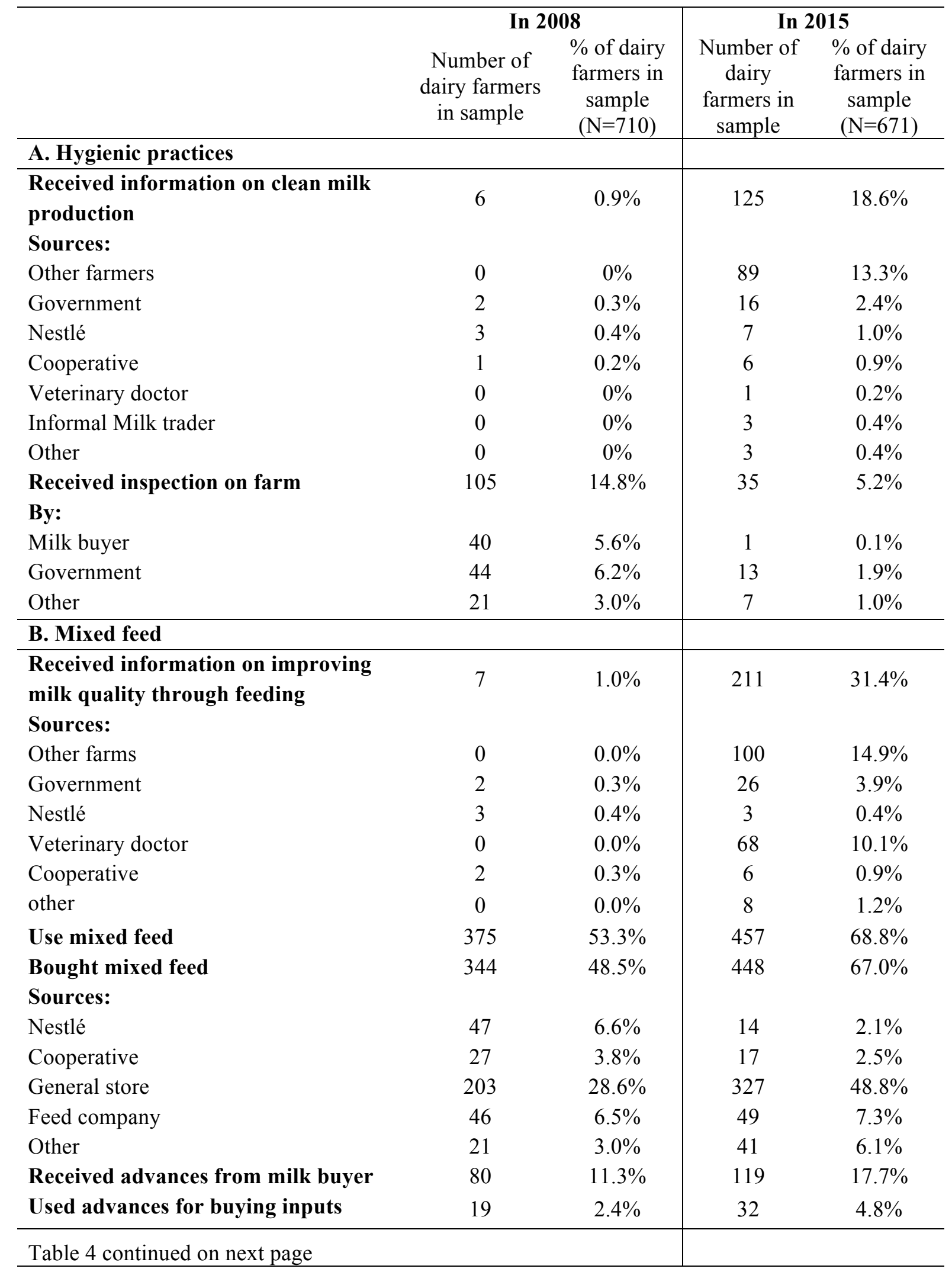




\begin{tabular}{lcc|cc}
\hline C. Cross-bred cows & & & & \\
\hline $\begin{array}{l}\text { Owns cross-bred DA } \\
\text { Received information on improving } \\
\text { milk quality through choice of breed }\end{array}$ & 283 & 39.8 & 333 & $49.6 \%$ \\
$\begin{array}{l}\text { Sources: } \\
\text { Other farms }\end{array}$ & 7 & $1.0 \%$ & 206 & $30.7 \%$ \\
$\begin{array}{l}\text { Government } \\
\text { Nestlé }\end{array}$ & 0 & $0.0 \%$ & 96 & $14.3 \%$ \\
Veterinary doctor & 2 & $0.3 \%$ & 23 & $3.4 \%$ \\
Cooperative & 0 & $0.3 \%$ & 2 & $0.3 \%$ \\
other & 2 & $0.0 \%$ & 72 & $10.9 \%$ \\
$\begin{array}{l}\text { Took a loan to finance purchase of } \\
\text { cross-bred cow }\end{array}$ & 1 & $0.3 \%$ & 4 & $0.5 \%$ \\
\hline Source: Survey data & 6 & $0.9 \%$ & 26 & $3.9 \%$ \\
\hline
\end{tabular}

Source: Survey data

Table 5. Dairy animals in the sample and Punjab

\begin{tabular}{c|cc|cc|c}
\hline \multicolumn{7}{c}{ In our sample } \\
\hline Number of female adult DA & \multicolumn{2}{|c|}{ In 2008 } & \multicolumn{2}{c}{ In 2015 } & $\begin{array}{c}\text { \% change } \\
\text { from 2008 }\end{array}$ \\
Cross-bred cows & 853 & $30.5 \%$ & 895 & $39.2 \%$ & $+12.9 \%$ \\
Indigenous cows & 47 & $1.7 \%$ & 14 & $0.6 \%$ & $-70.0 \%$ \\
Buffalos & 1894 & $67.8 \%$ & 1377 & $60.2 \%$ & $-27.3 \%$ \\
Total & 2794 & $100.0 \%$ & 2286 & $100.0 \%$ & $-18.2 \%$ \\
\hline
\end{tabular}

Source: Survey data 
Table 6. Summary statistics of variables used in econometric analysis by sample year

\begin{tabular}{|c|c|c|c|c|c|}
\hline \multirow{2}{*}{ Technologies } & \multirow[b]{3}{*}{ Index } & \multicolumn{2}{|c|}{2008 sample } & \multicolumn{2}{|c|}{2015 sample } \\
\hline & & & & & \\
\hline Hygiene & & 0.5 & $(0.1)$ & 0.7 & $(0.2)$ \\
\hline Use of mixed feed & $\%$ & 53.4 & $(49.9)$ & 68.8 & $(46.4)$ \\
\hline Share of cross-bred & share & 0.2 & $(0.3)$ & 0.3 & $(0.3)$ \\
\hline \multicolumn{6}{|l|}{ Farm size and income } \\
\hline Total no. of DA & $\mathrm{Nr}$ & 4.1 & $(4.3)$ & 3.5 & $(4.9)$ \\
\hline Land & Acres & 8.2 & $(10.4)$ & 9.8 & $(13.9)$ \\
\hline Asset index & Index & 0.3 & $(1.0)$ & 0.3 & $(1.0)$ \\
\hline \multicolumn{6}{|l|}{ Farm HH characteristics } \\
\hline Age HH head & Years & 50.5 & $(12.0)$ & 54.4 & $(14.1)$ \\
\hline $\mathrm{HH}$ head is female & $\%$ & 3.0 & $(17.1)$ & 6.3 & $(24.3)$ \\
\hline HH head education & Years & 5.4 & $(4.6)$ & 7.5 & $(5.0)$ \\
\hline $\mathrm{HH}$ size & $\mathrm{Nr}$ & 6.2 & $(5.6)$ & 6.0 & $(2.5)$ \\
\hline HH members over 55 & $\mathrm{Nr}$ & 0.7 & $(0.8)$ & 1.0 & $(1.0)$ \\
\hline No. of female adults in $\mathrm{HH}$ & $\mathrm{Nr}$ & 2.2 & $(1.1)$ & 2.2 & $(1.1)$ \\
\hline
\end{tabular}


Table 7. Technology adoption and value chain in Punjab.

\begin{tabular}{|c|c|c|c|}
\hline & $\begin{array}{l}\text { Hygiene index } \\
\text { (FE) }\end{array}$ & $\begin{array}{c}\text { Share of cross- } \\
\text { bred } \\
\text { (FE) }\end{array}$ & $\begin{array}{c}\text { Use of mixed feed } \\
\text { (LPM FE) }\end{array}$ \\
\hline \multicolumn{4}{|l|}{$\begin{array}{l}\text { Supply chain: dairy farm } \\
\text { switched to }\end{array}$} \\
\hline Nestlé & $\begin{array}{l}-0.0008 \\
(0.0491)\end{array}$ & $\begin{array}{c}0.0108 \\
(0.0480)\end{array}$ & $\begin{array}{c}0.0239 \\
(0.1060)\end{array}$ \\
\hline Cooperative & $\begin{array}{l}-0.0317 \\
(0.0267)\end{array}$ & $\begin{array}{c}0.0412 \\
(0.0444)\end{array}$ & $\begin{array}{c}0.0900 \\
(0.0850)\end{array}$ \\
\hline Private domestic firm & $\begin{array}{l}-0.0319 \\
(0.0286)\end{array}$ & $\begin{array}{c}0.0555 \\
(0.0444)\end{array}$ & $\begin{array}{c}0.0818 \\
(0.0936)\end{array}$ \\
\hline Informal milk traders & $\begin{array}{l}-0.0086 \\
(0.0225)\end{array}$ & $\begin{array}{l}-0.0285 \\
(0.0382)\end{array}$ & $\begin{array}{c}0.0622 \\
(0.0748)\end{array}$ \\
\hline Informally to households & $\begin{array}{l}-0.0233 \\
(0.0243) \\
\end{array}$ & $\begin{array}{l}-0.0525 \\
(0.0446) \\
\end{array}$ & $\begin{array}{c}0.1400 \\
(0.0870) \\
\end{array}$ \\
\hline \multicolumn{4}{|l|}{ Farm size and income } \\
\hline Total No. of DA & $\begin{array}{c}0.0292 \\
(0.0202)\end{array}$ & $\begin{array}{l}0.0924 * * * \\
(0.0300)\end{array}$ & $\begin{array}{l}0.2930 * * * \\
(0.0413)\end{array}$ \\
\hline Land & $\begin{array}{l}0.0223^{*} \\
(0.0126)\end{array}$ & $\begin{array}{l}-0.0078 \\
(0.0198)\end{array}$ & $\begin{array}{c}0.0382 \\
(0.0417)\end{array}$ \\
\hline Asset index & $\begin{array}{c}-0.0394 * * * \\
(0.0099)\end{array}$ & $\begin{array}{c}0.0073 \\
(0.0163)\end{array}$ & $\begin{array}{l}-0.0436 \\
(0.0326)\end{array}$ \\
\hline \multicolumn{4}{|l|}{ Farm-HH characteristics } \\
\hline Age HH head & $\begin{array}{l}-0.0001 \\
(0.0009)\end{array}$ & $\begin{array}{c}0.0013 \\
(0.0015)\end{array}$ & $\begin{array}{l}-0.0020 \\
(0.0024)\end{array}$ \\
\hline $\mathrm{HH}$ head is female & $\begin{array}{c}0.0507 \\
(0.0357)\end{array}$ & $\begin{array}{l}-0.1130^{*} \\
(0.0602)\end{array}$ & $\begin{array}{l}-0.0327 \\
(0.0978)\end{array}$ \\
\hline HH head education & $\begin{array}{l}-0.0005 \\
(0.0012)\end{array}$ & $\begin{array}{c}0.0010 \\
(0.0021)\end{array}$ & $\begin{array}{l}-0.0023 \\
(0.0036)\end{array}$ \\
\hline HH size & $\begin{array}{l}-0.0034 \\
(0.0042)\end{array}$ & $\begin{array}{l}-0.00429 \\
(0.0069)\end{array}$ & $\begin{array}{c}0.0036 \\
(0.0126)\end{array}$ \\
\hline HH members over 55 & $\begin{array}{l}-0.0087 \\
(0.0067)\end{array}$ & $\begin{array}{l}-0.0031 \\
(0.0105)\end{array}$ & $\begin{array}{c}0.0037 \\
(0.0195)\end{array}$ \\
\hline No. of female adults in $\mathrm{HH}$ & $\begin{array}{c}0.0084 \\
(0.0073)\end{array}$ & $\begin{array}{l}-0.0146 \\
(0.0116)\end{array}$ & $\begin{array}{c}0.0083 \\
(0.0215)\end{array}$ \\
\hline Year 2015 & $\begin{array}{c}0.1850 * * * \\
(0.0128)\end{array}$ & $\begin{array}{c}0.0857 * * * \\
(0.0207)\end{array}$ & $\begin{array}{l}0.1350 * * * \\
(0.0314)\end{array}$ \\
\hline Change HHH & $\begin{array}{l}-0.0282 \\
(0.0323)\end{array}$ & $\begin{array}{c}0.0828 \\
(0.0528)\end{array}$ & $\begin{array}{l}-0.0375 \\
(0.0976)\end{array}$ \\
\hline $\begin{array}{l}\text { Observations } \\
\mathrm{R}^{2}\end{array}$ & $\begin{array}{l}1,359 \\
0.457\end{array}$ & $\begin{array}{l}1,373 \\
0.110\end{array}$ & $\begin{array}{l}1,718 \\
0.640\end{array}$ \\
\hline
\end{tabular}

Note: Fixed effects models (FE) was chosen for hygiene index and cross-bred adoption, and linear probability model with fixed effects (LPM FE) was used for adoption of mixed feed. Robust standard errors (clustered at individual level) in parentheses $* * * p<0.01, * * p<0.05$, * $\mathrm{p}<0.1$ 
Table 8. Characteristics of large dairy farmers interviewed

\begin{tabular}{|c|c|c|c|c|c|c|c|c|c|}
\hline & Location & $\begin{array}{c}\text { Herd size } \\
\text { (no of } \\
\text { DA) }\end{array}$ & $\begin{array}{c}\text { Cross- } \\
\text { bred cows } \\
(\%) \\
\end{array}$ & $\begin{array}{l}\text { Land } \\
\text { size } \\
\text { (acres) }\end{array}$ & $\begin{array}{c}\text { Has } \\
\text { milking } \\
\text { machines }\end{array}$ & Milk buyer & $\begin{array}{l}\text { Services } \\
\text { from buyer }\end{array}$ & $\begin{array}{l}\text { Milk pick up } \\
\text { by the buyer }\end{array}$ & $\begin{array}{c}\text { On farm } \\
\text { inspections } \\
\text { from buyer }\end{array}$ \\
\hline Farmer 1 & Outskirts of Amritsar & 165 & $100 \%$ & 15 & yes & Verka & yes & yes & yes \\
\hline Farmer 2 & Outskirts of Amritsar & 122 & $100 \%$ & 60 & yes & Verka & yes & yes & yes \\
\hline Farmer 3 & Rural area in Amritsar & 90 & $100 \%$ & 45 & yes & private dairy & yes & yes & yes \\
\hline Farmer 4 & Outskirts of Ludhiana & 150 & $98.7 \%$ & 10 & yes & Verka & yes & yes & yes \\
\hline Farmer 5 & Outskirts of Ludhiana & 160 & $100 \%$ & 70 & yes & PDFA & yes & yes & yes \\
\hline Farmer 6 & Outskirts of Moga & 130 & $100 \%$ & 60 & yes & Nestlé & yes & yes & yes \\
\hline Farmer 7 & Rural area in Ludhiana & 105 & $98 \%$ & 50 & yes & private dairy & yes & yes & yes \\
\hline Farmer 8 & Rural area in Mansa & 70 & $100 \%$ & 1 & yes & households & yes & yes & yes \\
\hline Farmer 9 & Rural area in Mansa & 93 & 96.8 & / & yes & Nestlé & yes & yes & yes \\
\hline Farmer 10 & Rural area in Hoshiarpur & 70 & $92.9 \%$ & 30 & no & private dairy & yes & yes & yes \\
\hline Farmer 11 & Rural area in Firozpur & 103 & $98.1 \%$ & 30 & yes & Nestlé & yes & yes & yes \\
\hline Average & & $114 \mathrm{DA}$ & $96 \%$ & 41 acres & 10 out of 11 & & All & All & All \\
\hline
\end{tabular}

Source: Interviews large farmers 
Table 9. Characteristics of large sample farmers

\begin{tabular}{|c|c|c|c|c|c|c|c|c|}
\hline & $\begin{array}{l}\text { Herd size } \\
\text { (no of DA) }\end{array}$ & $\begin{array}{l}\text { Cross-bred } \\
\text { cows }(\%)\end{array}$ & $\begin{array}{l}\text { Land size } \\
\text { (acres) }\end{array}$ & $\begin{array}{c}\text { Has milking } \\
\text { machines }\end{array}$ & Milk buyer & $\begin{array}{l}\text { Services } \\
\text { from buyer }\end{array}$ & $\begin{array}{l}\text { Milk pick up } \\
\text { by the buyer }\end{array}$ & $\begin{array}{c}\text { On farm } \\
\text { inspections } \\
\text { from buyer }\end{array}$ \\
\hline Farmer 1 & 11 & $50 \%$ & 1 & no & cooperative & no & no & no \\
\hline Farmer 2 & 11 & $70 \%$ & 4 & no & cooperative & no & no & no \\
\hline Farmer 3 & 12 & $20 \%$ & 0 & no & households & no & no & no \\
\hline Farmer 4 & 12 & $100 \%$ & 12 & no & Nestlé & yes & no & yes \\
\hline Farmer 5 & 12 & $80 \%$ & 13 & no & cooperative & no & no & no \\
\hline Farmer 6 & 12 & $70 \%$ & 4 & yes & cooperative & no & yes & no \\
\hline Farmer 7 & 13 & $50 \%$ & 5 & no & informal milk traders & no & yes & no \\
\hline Farmer 8 & 13 & $20 \%$ & 22 & no & informal milk traders & yes & no & no \\
\hline Farmer 9 & 13 & $80 \%$ & 2 & no & Nestlé & no & no & no \\
\hline Farmer 10 & 13 & $0 \%$ & 40 & no & no sales & no & no & no \\
\hline Farmer 11 & 13 & $20 \%$ & 24 & no & Nestlé & no & no & no \\
\hline Farmer 12 & 13 & $30 \%$ & 7 & no & cooperative & yes & yes & no \\
\hline Farmer 13 & 14 & $40 \%$ & 7 & no & cooperative & no & no & no \\
\hline Farmer 14 & 15 & $20 \%$ & 17 & no & cooperative & no & no & no \\
\hline Farmer 15 & 15 & $100 \%$ & 7 & no & private domestic firm & no & no & no \\
\hline Farmer 16 & 15 & $70 \%$ & 5 & no & cooperative & no & yes & no \\
\hline Farmer 17 & 18 & $40 \%$ & 15 & / & cooperative & yes & no & no \\
\hline Farmer 18 & 18 & $90 \%$ & 10 & yes & cooperative & no & yes & no \\
\hline Farmer 19 & 19 & $100 \%$ & 11 & yes & PDFA & no & no & yes \\
\hline Farmer 20 & 20 & $50 \%$ & 15 & no & households & no & no & no \\
\hline Farmer 21 & 20 & $100 \%$ & 12 & yes & PDFA & no & no & yes \\
\hline Farmer 22 & 31 & $100 \%$ & 7 & yes & PDFA & no & no & yes \\
\hline Farmer 23 & 32 & $40 \%$ & 23 & no & Nestlé & no & no & no \\
\hline Farmer 24 & 96 & $90 \%$ & 22 & yes & PDFA & no & yes & yes \\
\hline Average & $19 \mathrm{DA}$ & $60 \%$ & 12 acres & 6 out of 24 & & 4 out of 24 & 6 out of 24 & 5 out of 24 \\
\hline
\end{tabular}

Source: Survey data 
Figure 1. Technology transfer through value chains

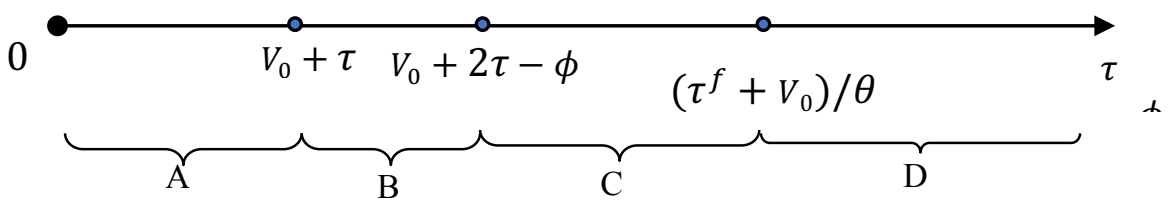

Figure 2. Income, vertical coordination, and technology adoption

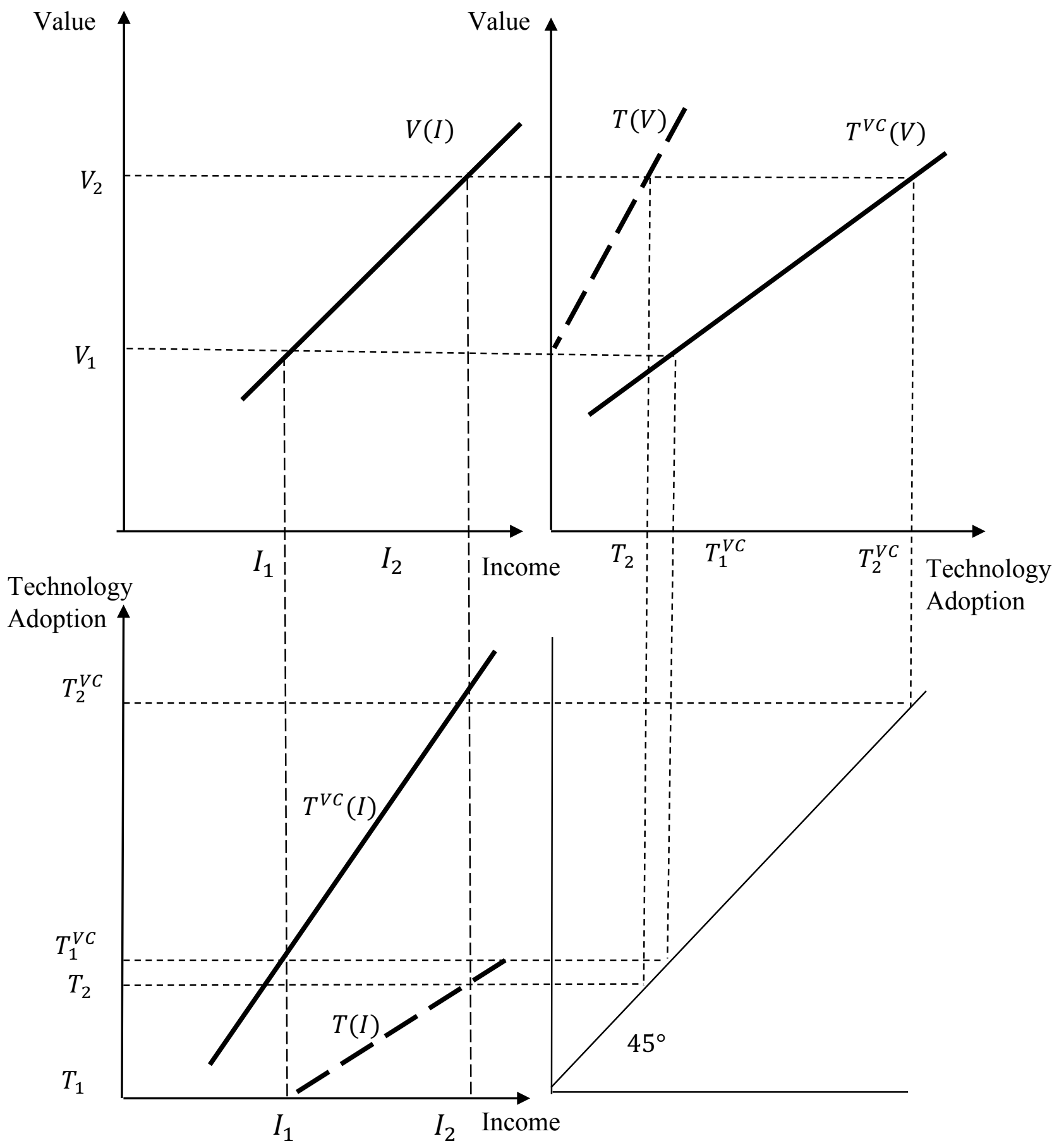


Figure 3. Growth of milk production in Punjab (\% growth since 2002)

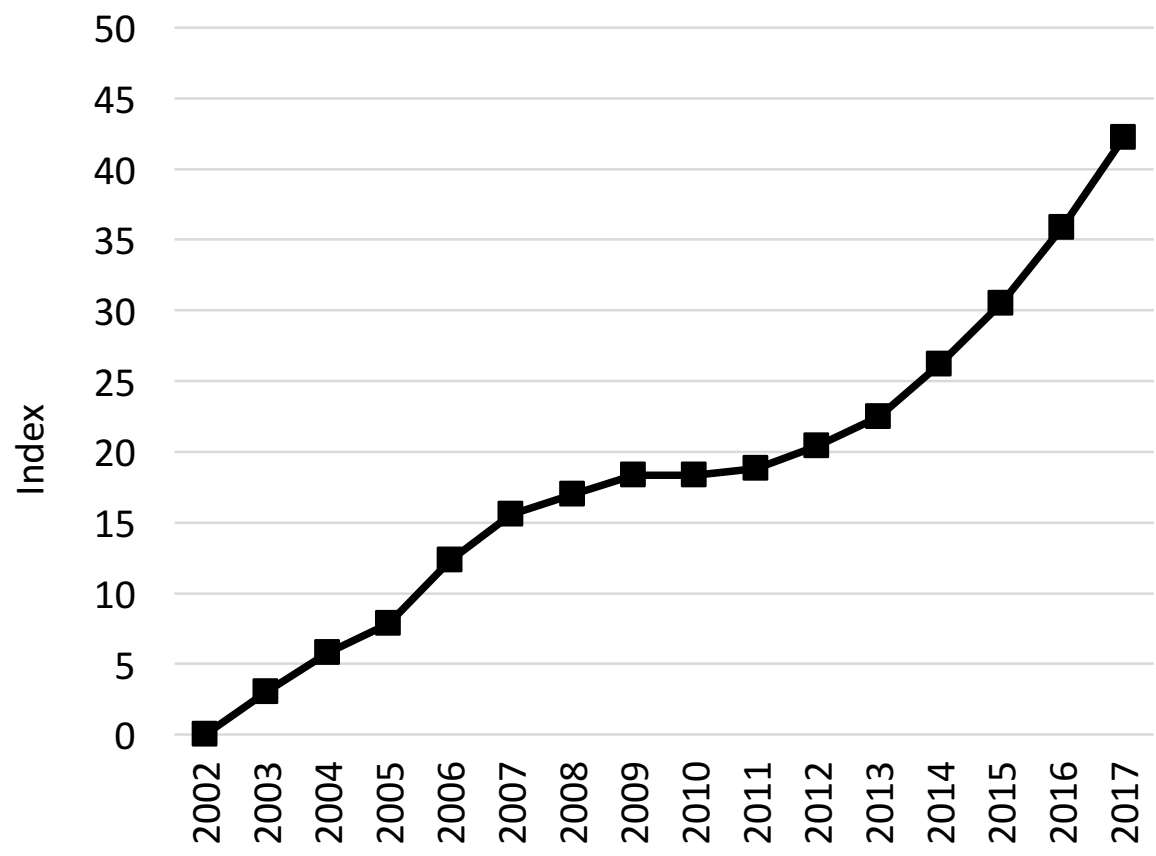

Source: National Dairy Development Board (2020)

Figure 4. Milk procurement structure in Punjab

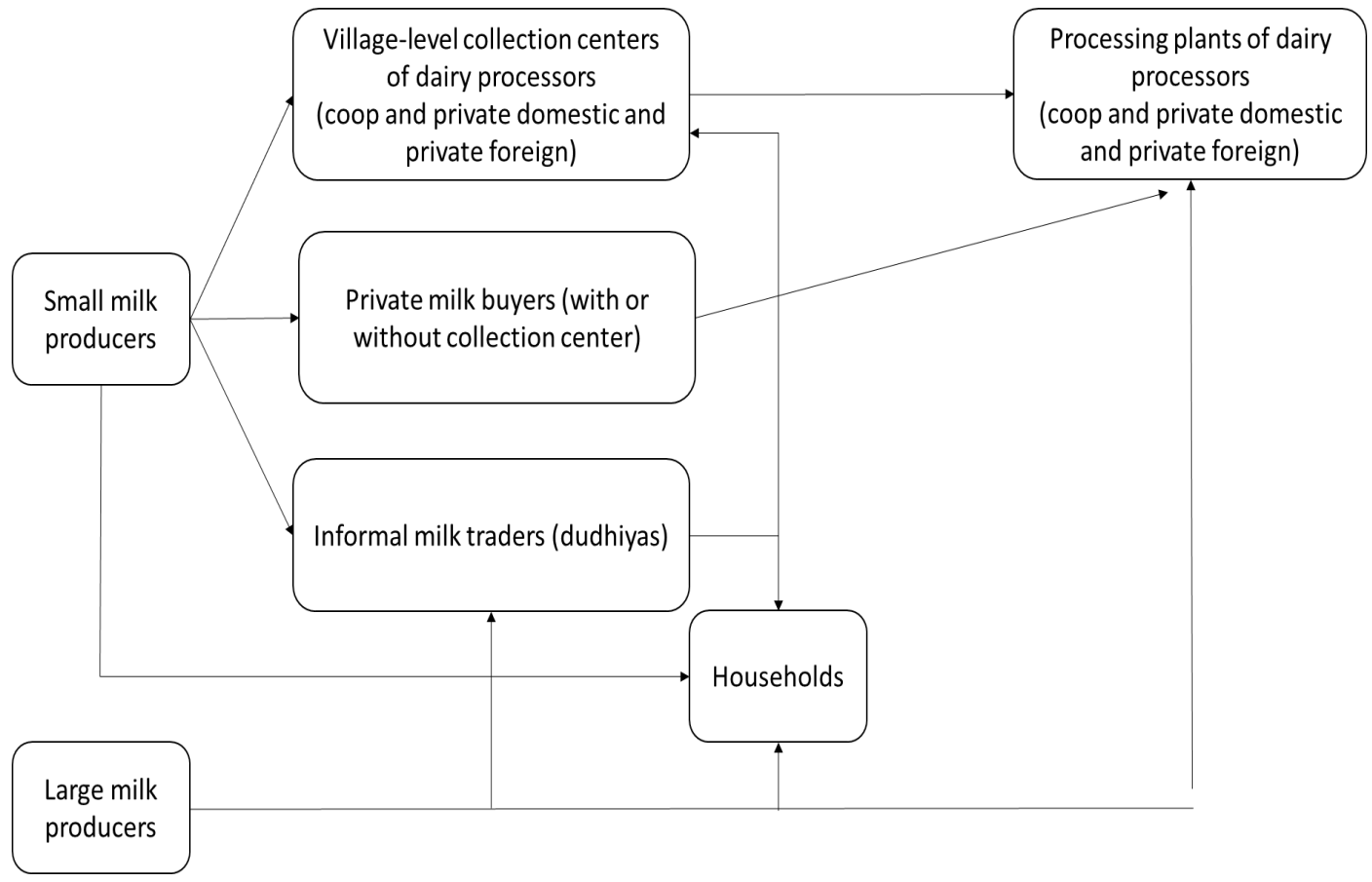

Source: Janssen and Swinnen (2019) 
Figure 5. Location of selected districts in Punjab, India

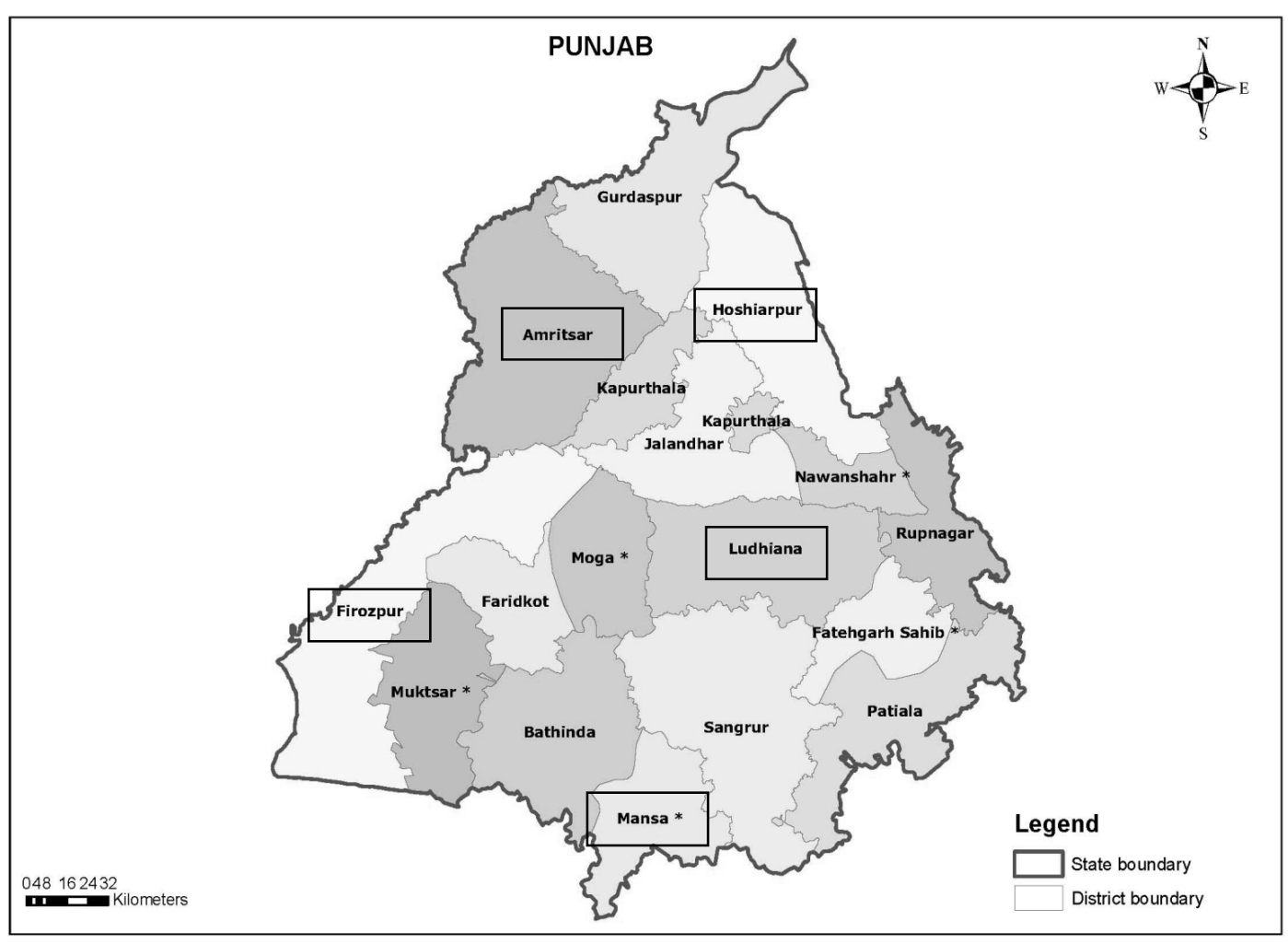

Selected districts

Source: Vandeplas et al. (2013) 
Figure 6. Hygiene index (level and growth) by adoption rate in 2008

a. level

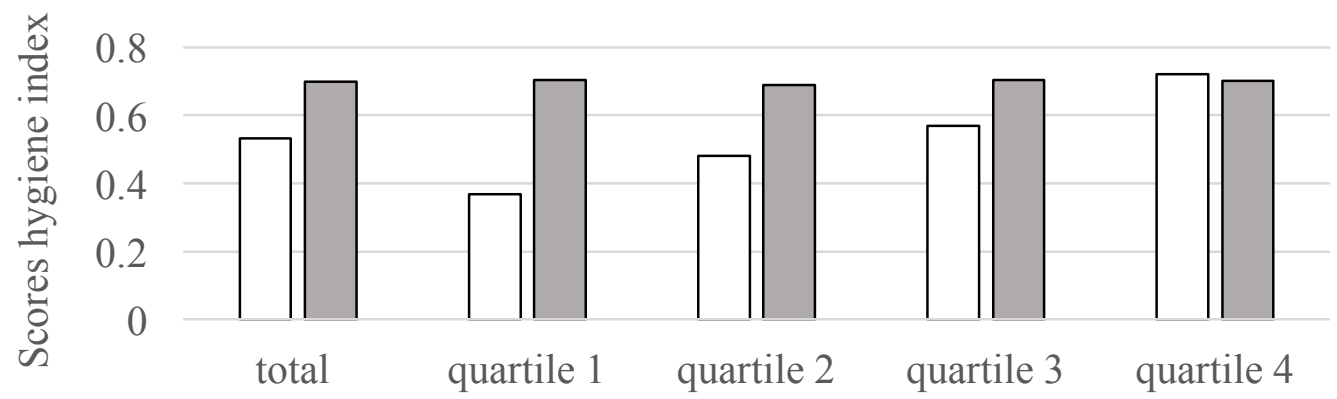

Quartiles hygiene index 2008

$\square 2008 \quad \square 2015$

b. growth

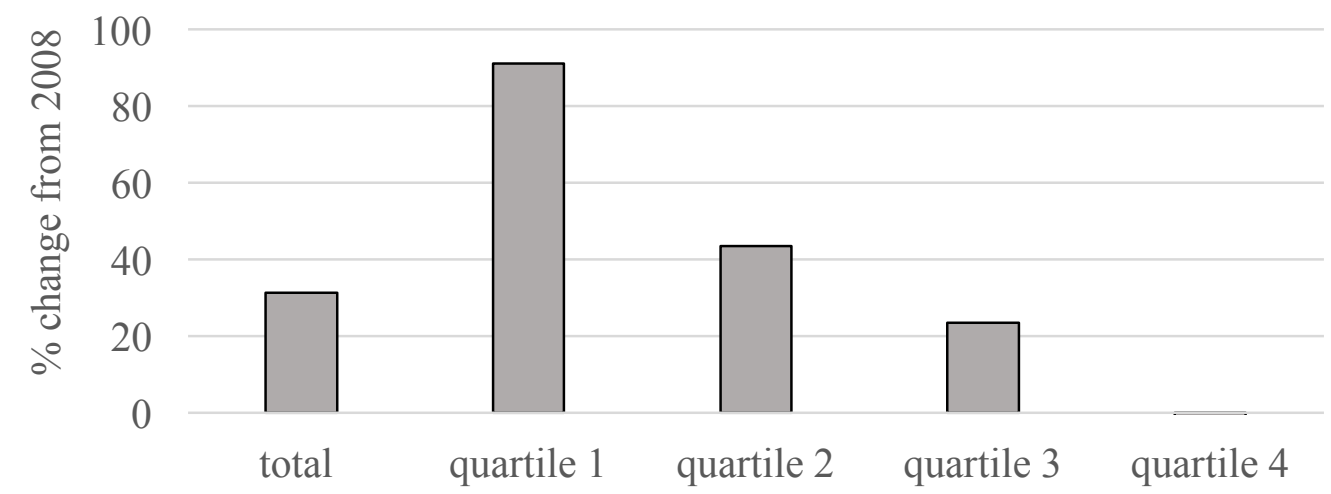

Quartiles hygiene index 2008

Source: Survey data 
Figure 7. Distribution of hygiene index in 2008 and 2015 in Punjab

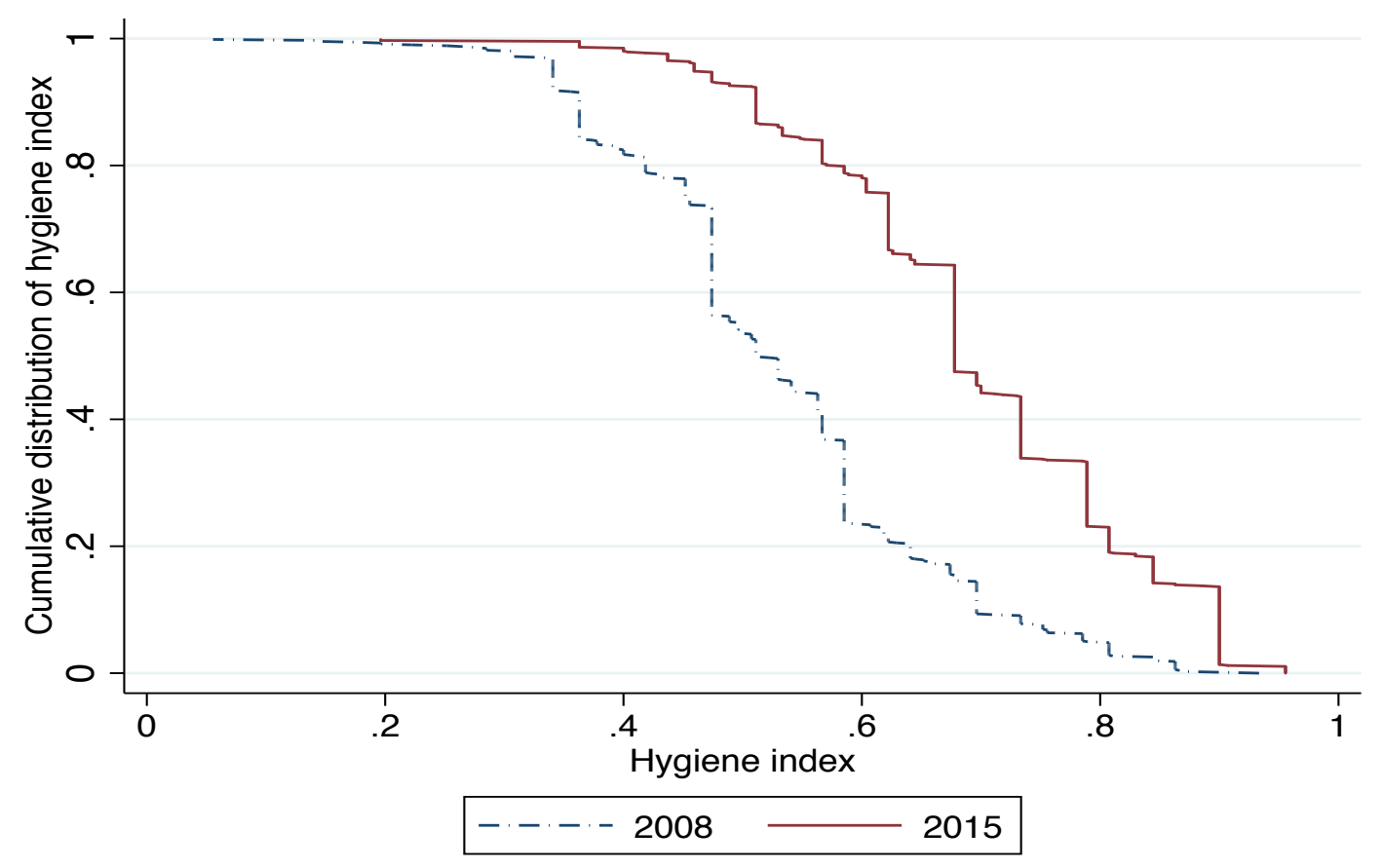

Source: Survey data

Figure 8. Hygiene index and milk marketing channels

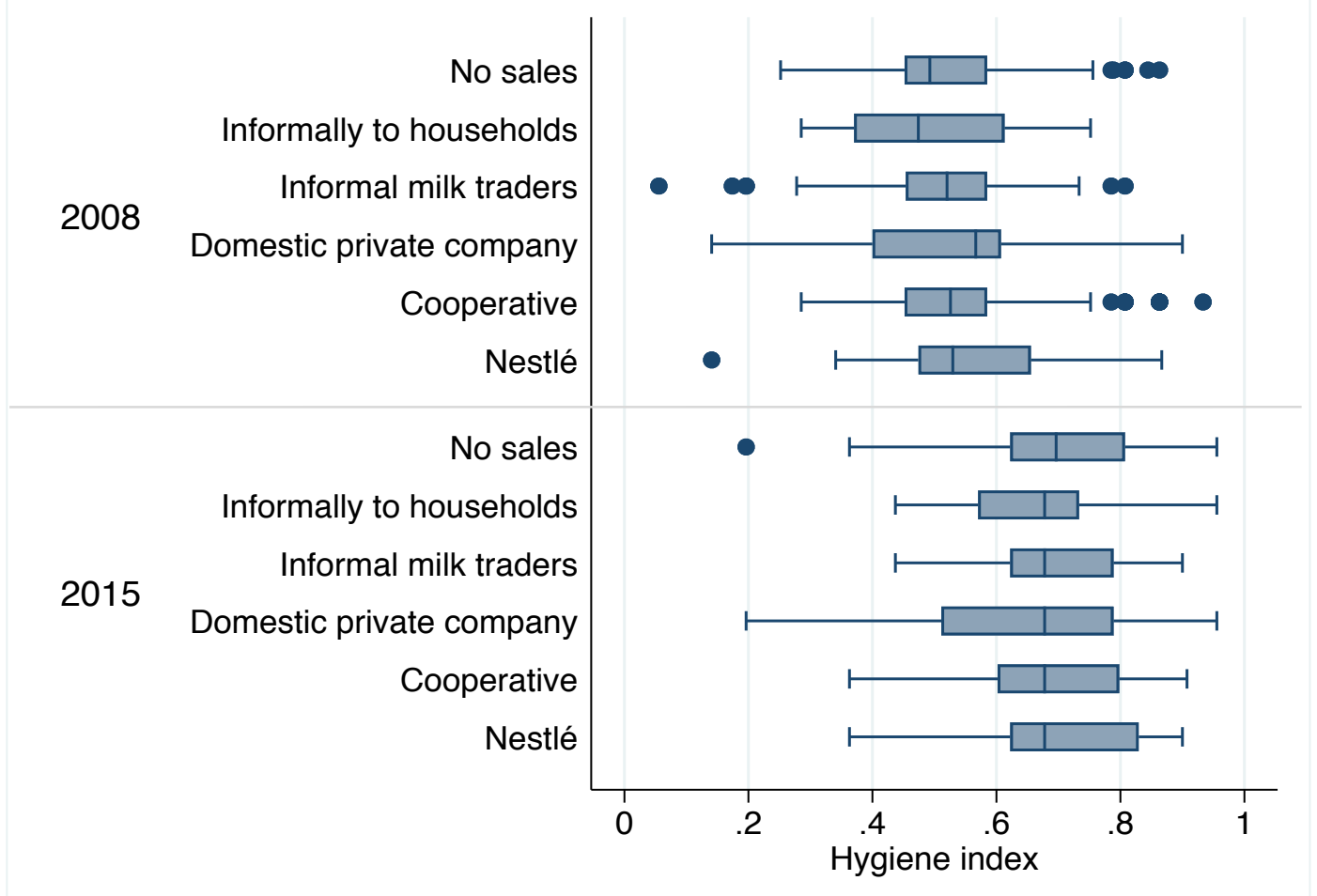

Source: Survey data 
Figure 9. Improvement in mixed feed use

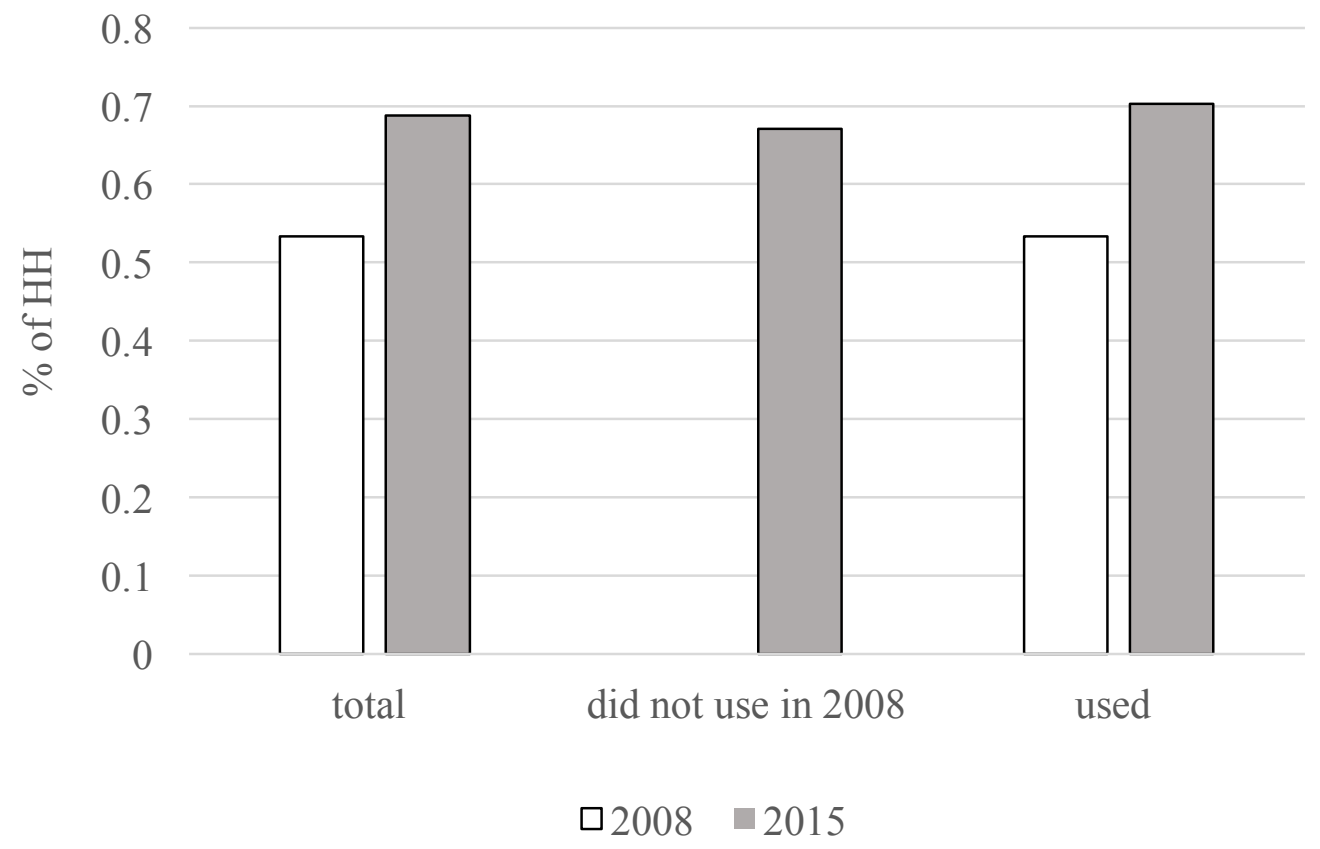

Source: Survey data

Figure 10. Mixed feed use and milk marketing channels

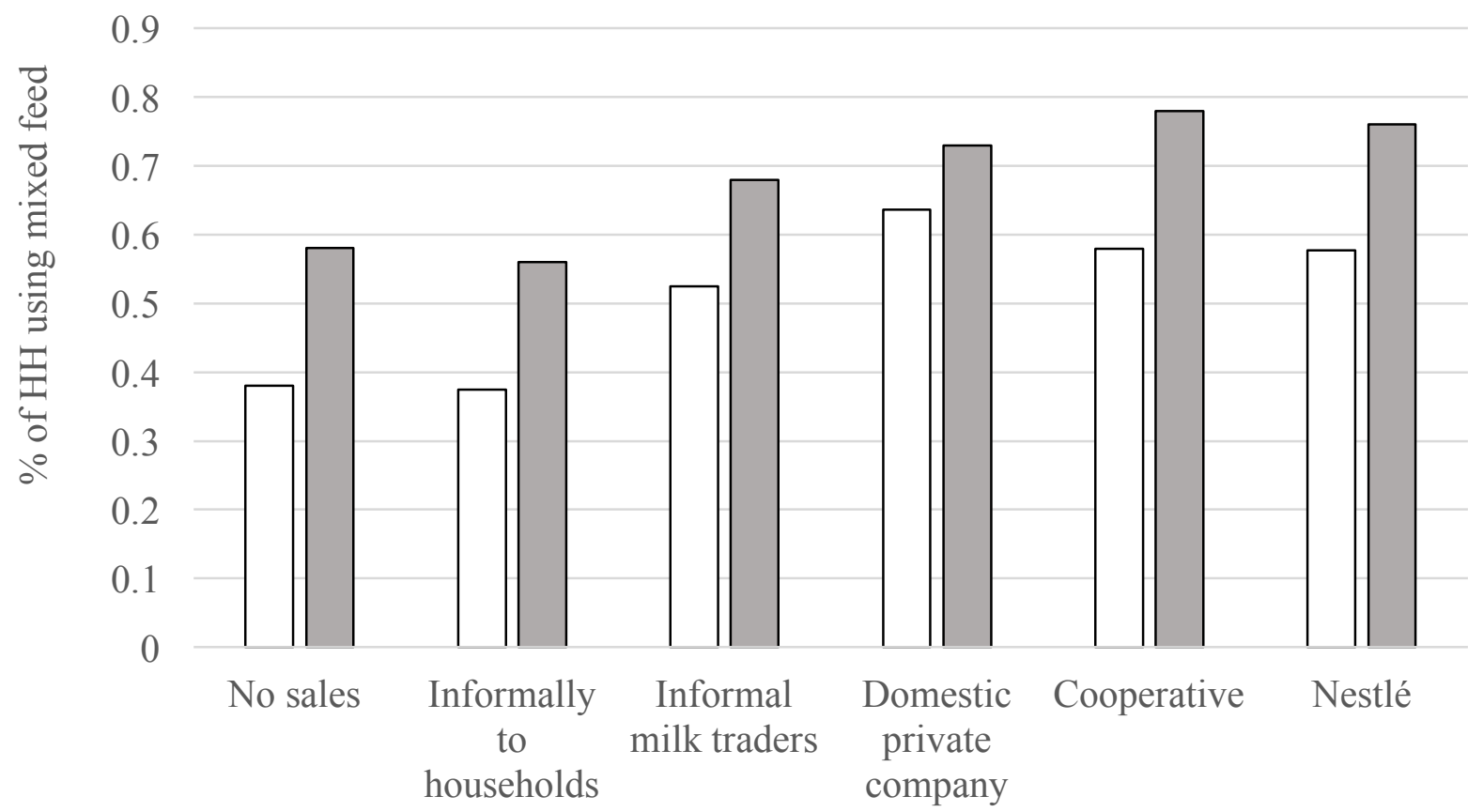

$\square 2008 \quad \square 2015$

Source: Survey data 
Figure 11. Share of cross-bred DA (\% and change) by adoption rate in 2008

a. share (\%)

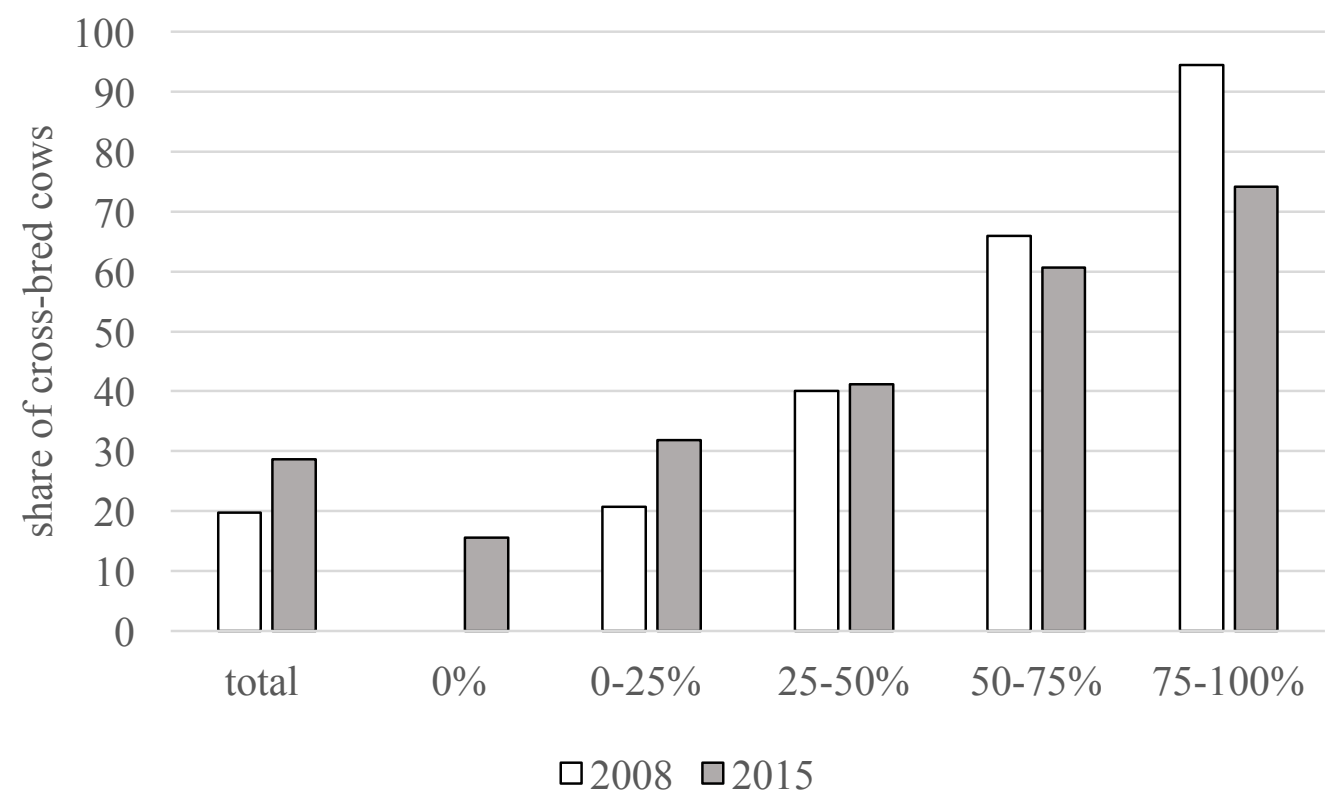

b. change 2015-2018

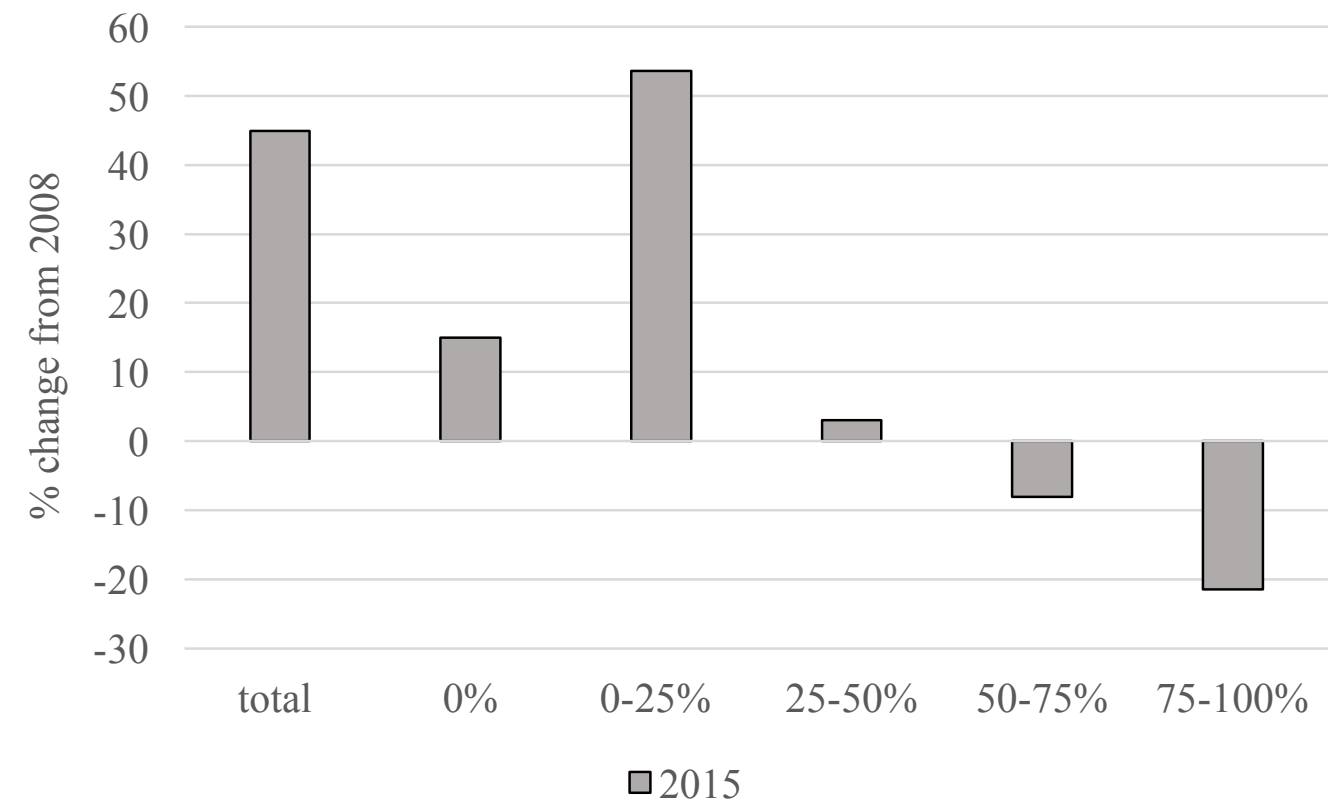

Source: Survey data 
Figure 12. Share of cross-bred cows across marketing channels (means)

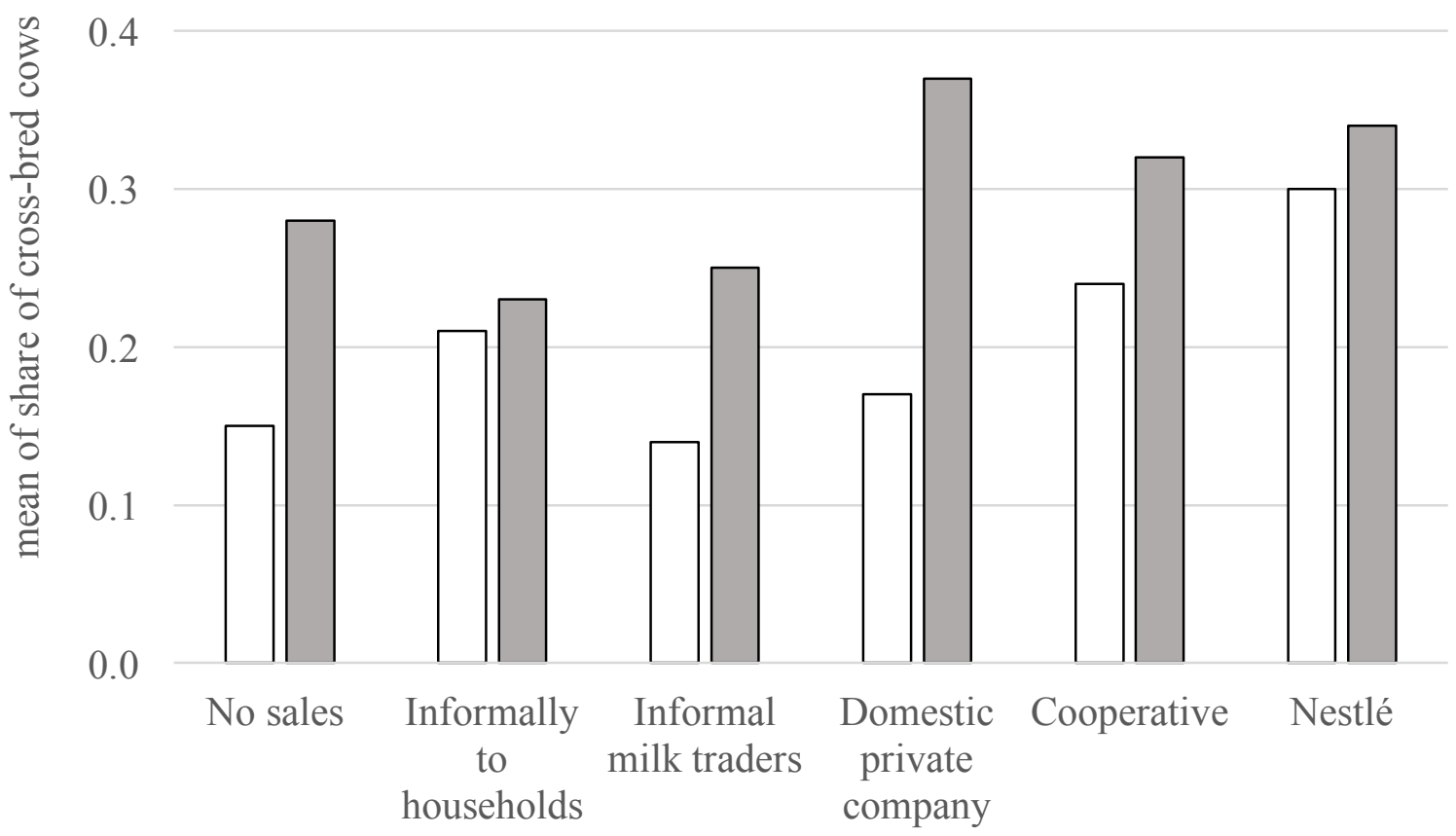

$\square 2008 \square 2015$

Source: Survey data 